Contract No. and Disclaimer:

This manuscript has been authored by Savannah River Nuclear Solutions, LLC under Contract No. DE-AC09-08SR22470 with the U.S. Department of Energy. The United States Government retains and the publisher, by accepting this article for publication, acknowledges that the United States Government retains a non-exclusive, paid-up, irrevocable, worldwide license to publish or reproduce the published form of this work, or allow others to do so, for United States Government purposes. 
Manuscript Number: HE-D-11-01499R1

Title: Hybrid sulfur cycle flowsheets for hydrogen production using high-temperature gas-cooled reactors

Article Type: Full Length Article

Keywords: Hydrogen production; nuclear heat application; hybrid sulfur cycle; process flowsheet; Aspen Plus; proton exchange membrane electrolyzer; bayonet decomposition reactor

Corresponding Author: Dr. Maximilian B. Gorensek, Ph.D., P.E.

Corresponding Author's Institution: Savannah River National Laboratory

First Author: Maximilian B. Gorensek, Ph.D., P.E.

Order of Authors: Maximilian B. Gorensek, Ph.D., P.E.

Abstract: Two hybrid sulfur (HyS) cycle process flowsheets intended for use with high-temperature gas-cooled reactors (HTGRs) are presented. The flowsheets were developed for the Next Generation Nuclear Plant (NGNP) program, and couple a proton exchange membrane (PEM) electrolyzer for the SO2-depolarized electrolysis step with a silicon carbide bayonet reactor for the high-temperature decomposition step. One presumes an HTGR reactor outlet temperature (ROT) of $950^{\circ} \mathrm{C}$, the other $750^{\circ} \mathrm{C}$. Performance was improved (over earlier flowsheets) by assuming that use of a more acidtolerant PEM, like acid-doped poly[2,2'-(m-phenylene)-5,5'-bibenzimidazole] (PBI), instead of Nafion ${ }^{\circledR}$, would allow higher anolyte acid concentrations. Lower ROT was accommodated by adding a direct contact exchange/quench column upstream from the bayonet reactor and dropping the decomposition pressure. Aspen Plus was used to develop material and energy balances. A net thermal efficiency of $44.0 \%$ to $47.6 \%$, higher heating value basis is projected for the $950^{\circ} \mathrm{C}$ case, dropping to $39.9 \%$ for the $750^{\circ} \mathrm{C}$ case. 


\section{Highlights for "Hybrid sulfur cycle flowsheets for hydrogen production using high- temperature gas-cooled reactors"}

- Two hybrid sulfur cycle flowsheets are presented that combine a bayonet decomposition reactor with a proton exchange membrane electrolyzer.

- Aspen Plus material and energy balances are provided.

- One flowsheet can be used with a $950^{\circ} \mathrm{C}$ reactor to make hydrogen at $44.0 \%$ to $47.6 \%$ net thermal efficiency, HHV basis.

- The other flowsheet can be used with a $750^{\circ} \mathrm{C}$ reactor to make hydrogen at $38.0 \%$ net thermal efficiency, HHV basis. 


\title{
Hybrid sulfur cycle flowsheets for hydrogen production using high-temperature gas-cooled reactors
}

\author{
Maximilian B. Gorensek ${ }^{*}$ \\ Process Modeling and Computational Chemistry Section, Savannah River National Laboratory, Aiken, SC 29808 \\ USA
}

\section{Abstract}

Two hybrid sulfur (HyS) cycle process flowsheets intended for use with high-temperature gas-cooled reactors (HTGRs) are presented. The flowsheets were developed for the Next Generation Nuclear Plant (NGNP) program, and couple a proton exchange membrane (PEM) electrolyzer for the $\mathrm{SO}_{2}$-depolarized electrolysis step with a silicon carbide bayonet reactor for the high-temperature decomposition step. One presumes an HTGR reactor outlet temperature (ROT) of $950^{\circ} \mathrm{C}$, the other $750^{\circ} \mathrm{C}$. Performance was improved (over earlier flowsheets) by assuming that use of a more acid-tolerant PEM, like acid-doped poly[2,2'-(m-phenylene)-5,5'bibenzimidazole] (PBI), instead of Nafion ${ }^{\circledR}$, would allow higher anolyte acid concentrations. Lower ROT was accommodated by adding a direct contact exchange/quench column upstream from the bayonet reactor and dropping the decomposition pressure. Aspen Plus was used to develop material and energy balances. A net thermal efficiency of $44.0 \%$ to $47.6 \%$, higher heating value basis is projected for the $950^{\circ} \mathrm{C}$ case, dropping to $39.9 \%$ for the $750^{\circ} \mathrm{C}$ case. Keywords: Hydrogen production; nuclear heat application; hybrid sulfur cycle; process flowsheet; Aspen Plus; proton exchange membrane electrolyzer; bayonet decomposition reactor

\footnotetext{
* Tel.: (803) 725-1314; Fax: (803) 725-8829;

E-mail address: maximilian.gorensek@ srnl.doe.gov
} 


\begin{tabular}{|c|c|}
\hline \multicolumn{2}{|c|}{ Acronyms } \\
\hline DOE & US Department of Energy \\
\hline DOE-NE & DOE Office of Nuclear Energy \\
\hline HHV & Higher heating value \\
\hline HTGR & High-temperature gas-cooled reactor \\
\hline HyS & Hybrid sulfur \\
\hline IHX & Intermediate heat exchanger \\
\hline NGNP & Next Generation Nuclear Plant \\
\hline NHI & Nuclear Hydrogen Initiative \\
\hline PBI & Poly[2,2'-( $m$-phenylene)-5,5'-bibenzimidazole $]$ \\
\hline PCU & Power conversion unit \\
\hline PEM & Proton exchange membrane (alternative definition: polymer electrolyte membrane) \\
\hline ROT & Reactor outlet temperature (nuclear reactor) \\
\hline SDE & $\mathrm{SO}_{2}$-depolarized electrolyzer \\
\hline SI & Sulfur-iodine \\
\hline SNL & Sandia National Laboratories \\
\hline SRNL & Savannah River National Laboratory \\
\hline USC & University of South Carolina \\
\hline
\end{tabular}




\section{1. Introduction}

4 The HyS cycle is one of the three primary hydrogen production methods that were being

5 developed for the US Department of Energy (DOE) Office of Nuclear Energy (DOE-NE) under

6 the Nuclear Hydrogen Initiative (NHI) [1, 2]. (The other two methods were high-temperature

7 electrolysis and the sulfur-iodine (SI) cycle.) Despite significant technical progress, the NHI was

8 discontinued by DOE in October, 2009 as part of a general reduction in support for hydrogen

9 energy research. Development of the HyS cycle under the NHI had been led by the Savannah

10 River National Laboratory (SRNL) [3], which proposed to couple a PEM-based $\mathrm{SO}_{2}$-depolarized

11 electrolyzer (SDE) [4] with a bayonet type high temperature sulfuric acid decomposition reactor

12 that had been designed and built by Sandia National Laboratories (SNL) for the SI cycle [5]. A

13 conceptual design for such a process was published previously [6].

14 Motivation for the NHI was provided by the DOE-NE's NGNP program [7], which seeks

15 to build an HTGR for demonstration purposes to advance commercialization of HTGRs for

16 electricity generation and process heat applications. One of the original purposes of NGNP was

17 to provide a high-temperature heat source for hydrogen production [8]. However, the NGNP

18 program was recently restructured to deemphasize hydrogen generation, and the design was

19 modified to focus on lower temperature operation aimed at other process heat applications [9],

20 such as high temperature steam generation. Nevertheless, several improvements to the HyS

21 process were made in the final days of the NHI that make a strong case for its further

22 development. Two of these are detailed in the following pages. 


\section{2. Background/Motivation}

The HyS cycle (Figure 1) is one of the simplest, all-fluids thermochemical cycles for

26 splitting water with a high-temperature heat source. Originally patented in 1975 by Brecher and

$27 \mathrm{Wu}[10]$, the only element it uses besides hydrogen and oxygen is sulfur, which is cycled

28 between the +4 and +6 oxidation states. HyS comprises two steps: one is the (high-temperature)

29 thermochemical decomposition of sulfuric acid $\left(\mathrm{H}_{2} \mathrm{SO}_{4}\right)$ to sulfur dioxide $\left(\mathrm{SO}_{2}\right)$, oxygen $\left(\mathrm{O}_{2}\right)$,

30 and water;

$$
\mathrm{H}_{2} \mathrm{SO}_{4}(a q) \rightarrow \mathrm{H}_{2} \mathrm{O}(g)+\mathrm{SO}_{2}(g)+\frac{1}{2} \mathrm{O}_{2}(g)
$$

32 the other is the $\mathrm{SO}_{2}$-depolarized electrolysis of water to $\mathrm{H}_{2} \mathrm{SO}_{4}$ and hydrogen $\left(\mathrm{H}_{2}\right)$.

$$
\mathrm{SO}_{2}(a q)+2 \mathrm{H}_{2} \mathrm{O}(l) \rightarrow \mathrm{H}_{2} \mathrm{SO}_{4}(a q)+\mathrm{H}_{2}(g), E^{\circ}=-0.156 \mathrm{~V}[11]
$$

34 It is the electrochemical nature of this second reaction that makes it a hybrid cycle. Researchers

35 at the SRNL and at the University of South Carolina (USC) have successfully used PEM

36 electrolyzers (Figure 2) for the SDE (sulfur oxidation) step, while others at SNL successfully

37 utilized a bayonet-type reactor (Figure 3) for the high-temperature sulfuric acid decomposition

38 (sulfur reduction) step. Coupling these two operations should result in a simple process that has

39 the potential to be more efficient and cost-effective for the massive production of hydrogen than

40 alkaline electrolysis.

41 The basic concepts of the HyS cycle have already been described in the literature. A

42 comprehensive review has also been published recently [12].

44 This was initially lowered to $950^{\circ} \mathrm{C}(1223 \mathrm{~K})[14]$ and finally to $750^{\circ} \mathrm{C}(1023 \mathrm{~K})$ [15] due to

45 concerns about the longevity of the intermediate heat exchanger (IHX). For comparison, the 46 flowsheet published previously [6] assumed an ROT of $945^{\circ} \mathrm{C}(1218 \mathrm{~K})$. All else being equal, 
47 lowering the ROT inevitably leads to lower energy efficiency, since the ideal efficiency of water-

48 splitting has a Carnot-type dependence on ROT as shown by Knoche and Funk [16].

49 Furthermore, a pinch analysis of the bayonet reactor [17] suggested that lowering the ROT below

$50825^{\circ} \mathrm{C}(1098 \mathrm{~K})$ would not result in a practical HyS process due to recuperation limitations within

51 the bayonet itself. These considerations prompted a careful reexamination of the flowsheet, since

52 the $685.8-\mathrm{kJ} / \mathrm{mol} \mathrm{H}_{2}$ energy requirement that was reported earlier [6] for the $945^{\circ} \mathrm{C}(1218 \mathrm{~K})$

53 ROT case corresponded to an HHV efficiency ${ }^{1}$ of only $41.7 \%$. For comparison, an alkaline

54 electrolysis process powered by an HTGR power plant could be expected to achieve an HHV

55 efficiency of about $36 \%$ [6].

\section{3. Approach}

The simplicity of the two key components of this process is an attractive feature that

59 leads to a relatively simple flowsheet. However, there is more to HyS than just these two

60 operations, and integrating them requires some compromises.

61 Given the choice, the SDE should be maintained at the highest possible conversion (to

62 minimize the recycle of unreacted $\mathrm{SO}_{2}$ ) and $\mathrm{H}_{2} \mathrm{SO}_{4}$ content (to minimize the need for further

63 concentration downstream) for efficiency considerations elsewhere in the process. However, the

64 SDE can not be operated at high conversion because the cell potential depends on the

65 concentration of $\mathrm{SO}_{2}$ at the anode [11]. Earlier work $[6,19]$ assumed that the SDE operates at

$6640 \% \mathrm{SO}_{2}$ utilization, requiring a fairly large recycle stream and leaving a significant $\mathrm{SO}_{2}$

67 concentration in the anolyte effluent. Consequently, unreacted $\mathrm{SO}_{2}$ needs to be recovered and

68 recycled before feeding the sulfuric acid product to the decomposition reactor. More importantly,

\footnotetext{
${ }^{1}$ The HHV, or higher heating value of $\mathrm{H}_{2}$ is $-286 \mathrm{~kJ} / \mathrm{mol}[18]$.
} 
69 the concentration of sulfuric acid in the anolyte is also limited. Higher $\mathrm{H}_{2} \mathrm{SO}_{4}$ concentration leads

70 to lower $\mathrm{SO}_{2}$ solubility and higher reversible potential [11]. It can also decrease the conductivity

71 of the PEM separator, especially Nafion ${ }^{\circledR}$, thereby increasing the cell potential [20]. Since

72 efficient operation of the SDE is favored by more dilute (sulfuric acid) anolyte, the concentration

73 of $\mathrm{H}_{2} \mathrm{SO}_{4}$ in the anolyte effluent also needs to be increased before it is fed to the bayonet reactor.

74 The high-temperature decomposition of $\mathrm{H}_{2} \mathrm{SO}_{4}$ is limited by thermodynamic equilibrium

75 and falls well short of complete conversion. This implies that unreacted $\mathrm{H}_{2} \mathrm{SO}_{4}$ needs to be

76 recovered and recycled in addition to the $\mathrm{SO}_{2}$ product having to be separated from the $\mathrm{O}_{2}$ co-

77 product before it can be fed to the SDE. The high-temperature heat requirement is determined by

78 the opportunity for recuperation within the bayonet. Previous work showed that the required heat

79 input is minimized by operating the reactor at the highest possible temperature and pressure, and

80 at a feed concentration of $80.1 \mathrm{wt} \% \mathrm{H}_{2} \mathrm{SO}_{4}$ [17]. A more concentrated acid feed would actually

81 increase the heating target, while feeding less concentrated acid would cause more water to be

82 vaporized and condensed with incomplete recuperation, thereby consuming more high-

83 temperature heat. Concentrations below $65 \mathrm{wt} \% \mathrm{H}_{2} \mathrm{SO}_{4}$ give heating targets in excess of 400

$84 \mathrm{~kJ} / \mathrm{mol} \mathrm{H}_{2}$ which, when combined with the other process heat and power needs, results in a net

85 thermal efficiency comparable to that of alkaline electrolysis. Since the HyS cycle has greater

86 complexity, it will not be more cost-effective than water electrolysis unless it has a significant

87 efficiency advantage. An obvious way to maximize efficiency is to operate the SDE at the

88 highest possible acid concentration without adversely affecting the cell potential. 
90

91

92

93

94

95

96

97

98

99

100

101

102

103

104

105

106

107

108

109

110

111

112

\subsection{High-temperature $\left(950^{\circ} \mathrm{C} \mathrm{ROT}\right)$ flowsheet}

The first modification to the original [6] HyS process was made in an effort to improve the net thermal efficiency at the high temperature end, which was only $41.7 \%$, HHV basis as noted in Section 2. The anolyte acid concentration limitation was removed by assuming the use of an alternative PEM material such as acid-doped PBI instead of Nafion ${ }^{\circledR}$. The electrical resistivity of acid-doped PBI membranes, which can operate at much higher temperatures than Nafion ${ }^{\circledR}$, actually decreases with acid concentration [21]. (Such membranes were not actually tested in the SDE at SRNL because HyS development under the NHI was discontinued before they could be.) It was assumed, then, that the SDE uses a PEM capable of operating at 65 wt $\%$ $\mathrm{H}_{2} \mathrm{SO}_{4}$ in the anolyte and at temperatures of 120 to $140^{\circ} \mathrm{C}$. (Reversible cell potential increases with acid concentration and temperature [11], so operating at higher temperatures or concentrations than this may be limited by thermodynamic considerations.)

The existing HyS flowsheet [19] was modified to reflect operation of the SDE at $120^{\circ} \mathrm{C}$ and $65 \mathrm{wt} \% \mathrm{H}_{2} \mathrm{SO}_{4}$ in the anolyte product. $\mathrm{SO}_{2}$ conversion was also increased from $40 \%$ to $50 \%$, and a cell potential of $0.6 \mathrm{~V}$ imposed. (SDE operation at $0.6 \mathrm{~V}$ and $0.5 \mathrm{~A} / \mathrm{cm}^{2}$ was the development target for SRNL and should be attainable with acid-doped PBI PEMs.) Water flux across the membrane was set to maintain a ratio of $1 \mathrm{~mol} \mathrm{H}_{2} \mathrm{O} / \mathrm{mol} \mathrm{H}_{2}$ product despite the much lower water content of acid-doped PBI and other PEM alternatives (compared to Nafion®).

Since a significant water activity gradient will exist between the cathode and anode, it was assumed that the large driving force for water transport would compensate for the reduced water content of the new PEM material.

Raising the cell temperature allows heat dissipated in the SDE due to overpotentials to be recovered in the acid concentration step downstream. Increasing conversion reduces the quantity 
113 of unreacted $\mathrm{SO}_{2}$ that has to be removed and recycled. Raising the anolyte product acid

114 concentration from 50 to $65 \mathrm{wt} \% \mathrm{H}_{2} \mathrm{SO}_{4}$ allows the quantity of water that has to be removed in

115 the concentration step (in order to increase the acid concentration of the bayonet reactor feed to

$11675 \mathrm{wt} \% \mathrm{H}_{2} \mathrm{SO}_{4}$ ) to be reduced by roughly two-thirds. This means less than half as much energy is

117 needed to achieve the necessary concentration, so nearly all of the heat input can be provided by

118 recuperation from the SDE and the bayonet reactor.

119 Unfortunately, water recovered in the acid concentration step is needed to absorb $\mathrm{SO}_{2}$

120 from the uncondensed product of the bayonet decomposition reactor. Since less water is now

121 available for the $\mathrm{O}_{2} / \mathrm{SO}_{2}$ separation, a single absorber is no longer sufficient because it would

122 leave too much $\mathrm{SO}_{2}$ behind in the oxygen product.

123 The addition of an absorber/stripper combination reduces the $\mathrm{SO}_{2}$ content of the oxygen

124 co-product to $\leq 1 \mathrm{ppm}$ using conventional process equipment and without introducing any new

125 reagents. Water is the solvent; the absorber operates at the pressure of the SDE, while the

126 stripper operates at atmospheric pressure, allowing low-pressure steam or recuperation to provide

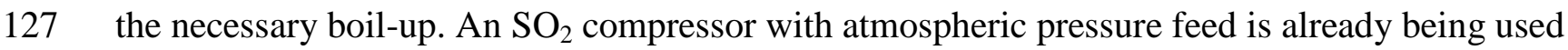

128 to recycle unconverted $\mathrm{SO}_{2}$ recovered from the anolyte product, so the overhead from the

129 stripper can be easily added to the recycle compressor feed.

\section{$131 \quad 3.2 . \quad$ Low-temperature $\left(750^{\circ} \mathrm{C}\right.$ ROT $)$ flowsheet}

132 A second set of modifications was made in an effort to accommodate the decrease in

133 ROT from 950 to $750^{\circ} \mathrm{C}$ for the NGNP program, leading to a new process flowsheet. An earlier

134 pinch analysis had shown that the minimum high-temperature heat requirement (per unit of $\mathrm{H}_{2}$

135 production) for the bayonet reactor increases with decreasing operating temperature (Figure 8 in 
136 reference [17]). This results from the unfavorable shift in equilibrium with lower temperatures as

137 well as from changes in internal recuperation within the bayonet. $\mathrm{H}_{2} \mathrm{SO}_{4}$ conversion also suffers,

138 leading to larger quantities of unconverted acid that need to be re-concentrated and recycled. To

139 counter-act the effects of operation with a catalyst bed exit temperature below $700^{\circ} \mathrm{C}$ (as

140 mandated by an ROT of $750^{\circ} \mathrm{C}$ ), the operating pressure of the bayonet was first lowered to 12

141 bar. This helped minimize the high-temperature heat requirement (e.g. see the $700^{\circ} \mathrm{C}$ curve in

142 Figure 9 in reference [17]) while recovering at least some of the lost $\mathrm{H}_{2} \mathrm{SO}_{4}$ conversion. A direct

143 contact exchange/quench column was then placed upstream of the bayonet to take advantage of

144 the favorable vapor-liquid equilibrium for the $\mathrm{H}_{2} \mathrm{O}-\mathrm{H}_{2} \mathrm{SO}_{4}$ system and trap unconverted acid in

145 the liquid phase. This eliminated the unconverted acid recycle stream present in the earlier

146 flowsheet $[6,19]$. The concentration of the vacuum column bottoms product was increased from

14775 to $90 \mathrm{wt} \% \mathrm{H}_{2} \mathrm{SO}_{4}$ to reduce the amount of water being fed to the bayonet reactor/quench

148 column combination (since every mole of water fed exits the loop in the quench overhead and

149 has to be vaporized using HTGR heat). Finally, the bayonet effluent was cooled by heat

150 exchange with heat sinks elsewhere in the process using a DOWTHERM ${ }^{\mathrm{TM}} \mathrm{G}$ commercial heat

151 transfer fluid loop before feeding it to the bottom of the direct contact exchange/quench column.

152 This provided a significant source of intermediate temperature heat, while diluting the bayonet

153 feed to a near optimal $76 \mathrm{wt} \% \mathrm{H}_{2} \mathrm{SO}_{4}$. The net effect of these changes was attainment of an

154 acceptable level for the high-temperature heat requirement for the bayonet reactor while

155 providing sufficient recuperation from the decomposition reaction product streams to eliminate

156 the need for any additional heat input to the balance of the flowsheet. 


\section{4. Results}

Aspen Plus (version 7.1) [22] was used to simulate the flowsheets and determine the

160 performance of individual unit operations. Specific details concerning modeling methodology

161 are available in reference [19]. Aspen Energy Analyzer (version 7.1) [23] was used to determine

162 the performance of the bayonet reactor from a pinch analysis based on Aspen Plus simulation

163 data. The details of that calculation are available in reference [17].

\subsection{High-temperature $\left(950^{\circ} \mathrm{C} \mathrm{ROT}\right)$ flowsheet}

The design basis for the $950^{\circ} \mathrm{C}$ ROT HyS process is summarized below in the first data

167 column in Table 1. Rather than pick a specific production rate to match an assumed NGNP

168 heat/power output, the flowsheet was sized at a nominal 1-kmol/sec production rate. This allows

169 all material (molar, mass, and volumetric) and energy (heat and work) flow rates to be multiplied

170 by the actual hydrogen production rate (in $\mathrm{kmol} / \mathrm{sec}$ ) to determine their values for a given

171 application. Note that a $950^{\circ} \mathrm{C}$ ROT implies hot helium is supplied to the bayonet reactor at

$172900^{\circ} \mathrm{C}$ due to an assumed $50^{\circ} \mathrm{C}$ temperature drop across the IHX. Furthermore, the peak

173 temperature of $\mathrm{H}_{2} \mathrm{SO}_{4}$ decomposition, which occurs inside the tip of the bayonet (at the outlet of

174 the catalyst bed) is $875^{\circ} \mathrm{C}$ due to an assumed minimum temperature difference of $25^{\circ} \mathrm{C}$ between

175 the helium heat transfer medium and the process fluid. Figure 4 illustrates the heat transfer

176 mechanism between the nuclear heat source and the bayonet reactor. The power conversion

177 efficiency of $48 \%$, which assumes that the source of electricity is a power conversion unit (PCU)

178 driven by a $950^{\circ} \mathrm{C}$ ROT HTGR, is consistent with published projections for NGNP [24]. This

179 PCU could be driven by the same HTGR as the HyS process, or by a separate, electric power 180 HTGR. 
The $950^{\circ} \mathrm{C}$ ROT HyS flowsheet is shown in Figure 5. The stream summary is presented

182 in Table 2. Figure 6 details the heat exchanger network used to preheat the vacuum column feed;

183 fresh sulfuric acid feed is preheated by interchange with the anolyte and catholyte streams, while

184 recycled unconverted acid is preheated by interchange with the bayonet vapor product stream.

185 The details of the HyS flowsheet are described at length in an earlier paper [6]. The

186 flowsheet in Figure 5 differs from the earlier flowsheet in the following respects: higher $\mathrm{SO}_{2}$

187 conversion in the SDE, EL-01 (50 instead of 40\%); higher anolyte acid concentration (65 instead

188 of $\left.50 \mathrm{wt} \% \mathrm{H}_{2} \mathrm{SO}_{4}\right)$; higher SDE operating temperature $\left(120\right.$ instead of $\left.100^{\circ} \mathrm{C}\right)$; detailed heat

189 exchange network (EX-01 through EX-05) with realistic pressure drops (instead of simple stream

190 heaters and coolers connected by heat streams); rigorous vacuum ejector design (instead of fixed

191 entrainment ratio); the overhead product from the original $\mathrm{SO}_{2}$ absorber, $\mathrm{TO}-02$ is treated in a

192 new absorber/stripper combination (TO-03 and TO-04).

193 An energy balance was developed from the simulation results. This is presented in the

194 first energy utilization summary, Table 3. Included are the duties and power requirements for all

195 heat exchangers, compressors, pumps, and other energy consumers. Heating and cooling curves

196 were generated using Aspen Plus for all process streams undergoing heat exchange and checked

197 for feasibility. No temperature cross-over was detected; adequate temperature differences were

198 maintained for counter-current heat exchange.

The minimum high-temperature heat requirement for the bayonet reactor was determined

200 from a pinch analysis following the methodology described in reference [17]. The heating

201 (annular flow in) and cooling (center flow out) curves are shown in Figure 7, while the utility

202 composite curve, which demonstrates the operating limits for the secondary helium coolant, is

203 provided as Figure 8. 
As shown in Table 3, the net energy efficiency of the $950^{\circ} \mathrm{C}$ ROT HyS flowsheet is $44.0 \%$, HHV basis if no suitable waste heat source is available, and 47.6\%, HHV basis if waste heat from elsewhere in the plant can be exploited to make low-pressure steam. (For comparison,

207 alkaline electrolysis could be expected to achieve 38.6\% HHV efficiency when coupled with a 208 PCU operating at $48 \%$ conversion efficiency.) This increase (from $41.7 \%$ ) is attributable to the 209 combined effects of the higher NGNP PCU conversion efficiency ( $48 \%$ instead of $45 \%$ ), the

210 increase in anolyte acid concentration (from 50 to $65 \mathrm{wt} \% \mathrm{H}_{2} \mathrm{SO}_{4}$ ) assumed to be attainable with

211 an acid-tolerant PEM, and the increase in $\mathrm{SDE} \mathrm{SO}_{2}$ conversion (from 40 to 50\%). It should be

212 noted that the energy required to provide cooling water is not included in this efficiency

213 calculation since the actual amount depends on the type of cooling water system used and is not 214 expected to have a major impact.

\section{4.2. Low-temperature $\left(750^{\circ} \mathrm{C}\right.$ ROT $)$ flowsheet}

217 The design basis for the $750^{\circ} \mathrm{C}$ ROT HyS process is summarized below in the second 218 data column in Table 1 . As is the case for the $950^{\circ} \mathrm{C}$ ROT version, the flowsheet was sized at a 219 nominal 1-kmol/sec production rate, allowing the values of all material (molar, mass, and 220 volumetric) and energy (heat and work) flow rates for a given application to be determined by

221 simply multiplying the tabulated value by the actual hydrogen production rate (in $\mathrm{kmol} / \mathrm{sec}$ ).

222 Note that a $750^{\circ} \mathrm{C}$ ROT implies hot helium is supplied to the bayonet reactor at $700^{\circ} \mathrm{C}$ due to an 223 assumed $50^{\circ} \mathrm{C}$ temperature drop across the $\mathrm{IHX}$. An additional $25^{\circ} \mathrm{C}$ drop between the helium 224 heat transfer medium and the process fluid results in a $675^{\circ} \mathrm{C}$ peak temperature of $\mathrm{H}_{2} \mathrm{SO}_{4}$ 225 decomposition inside the tip of the bayonet (at the outlet of the catalyst bed). Heat transfer 226 follows the same path as in Figure 4; the only difference is that the stream temperatures are 
$227200^{\circ} \mathrm{C}$ lower. The power conversion efficiency of $45 \%$ assumes that electricity is provided by a

$228750^{\circ} \mathrm{C}$ ROT HTGR PCU and is consistent with efficiency projections for NGNP [24]. This PCU

229 could be driven by the same HTGR as the HyS process, or by a separate, electric power HTGR.

230 The $750^{\circ} \mathrm{C}$ ROT HyS flowsheet is shown in Figure 9 and the corresponding stream

231 summary is presented in Table 4. Besides the lower bayonet reactor operating temperature and

232 pressure, this flowsheet differs from that in Figure 5 by the addition of a quench column/direct

233 contact exchanger (new TO-02) and elimination of the unconverted acid stream that was

234 recycled to the vacuum column (TO-01). The concentration of the vacuum column bottoms is

235 also increased from 75 to $90 \mathrm{wt} \% \mathrm{H}_{2} \mathrm{SO}_{4}$. Another difference is the addition of the

236 DOWTHERM ${ }^{\mathrm{TM}} \mathrm{G}$ heat transfer fluid loop, which recovers intermediate temperature heat from

237 the bayonet reactor product in heat exchangers HX-01 and HX-02 as well as the quench column

238 (TO-02) condenser, and uses it to heat the vacuum column (TO-01) and $\mathrm{SO}_{2}$ stripper (TO-05)

239 reboilers as well as the steam generator (SG-01) for the vacuum ejectors. As a result, no external

240 steam heat source is needed; all of the necessary heat is provided by the HTGR heat source

241 through the bayonet reactor. Finally, the addition of some and removal of other unit operations

242 resulted in changes in many stream and equipment identification numbers (e.g. TO-03, TO-04,

243 and TO-05 were changed to TO-04, TO-05, and TO-06, respectively).

244 An energy balance was developed from the simulation results. This is presented in the

245 second energy utilization summary (Table 5). Included are the duties and power requirements for

246 all heat exchangers, compressors, pumps, and other energy consumers. Heating and cooling

247 curves were generated using Aspen Plus for all process streams undergoing heat exchange and

248 checked for feasibility. No temperature cross-over was detected; adequate temperature

249 differences were maintained for counter-current heat exchange. 
The minimum high-temperature heat requirement for the bayonet reactor was determined

251 from a pinch analysis following the methodology described in reference [17]. The heating

252 (annular flow in) and cooling (center flow out) curves are shown in Figure 10, while the utility

253 composite curve, which demonstrates the operating limits for the secondary helium coolant, is

254 provided as Figure 11.

As shown in Table 5, the net energy efficiency of the $750^{\circ} \mathrm{C}$ ROT HyS flowsheet is 39.9\%, HHV basis. (Alkaline electrolysis coupled with a PCU operating at $45 \%$ conversion 257 efficiency would have an HHV efficiency of $36.2 \%$ in comparison.) This is about 1 percentage 258 point lower than expected, based on the drop in energy efficiency for the NGNP PCU (from 48 259 to $45 \%$ ) when lowering the ROT from 950 to $750^{\circ} \mathrm{C}$. The most likely cause is the significantly 260 increased high-temperature heat requirement for the bayonet reactor, RX-01, (428.3 instead of $261340.2 \mathrm{~kJ} / \mathrm{mol} \mathrm{SO}_{2}$ ) which implies less efficient utilization. It should be noted again that this 262 number does not include the energy required to provide cooling water. However, the actual 263 power consumption depends on the type of cooling water system used and is not expected to 264 have a significant impact on efficiency.

\section{Discussion}

The two new HyS flowsheets presented in Section 4 are projected to achieve significantly 268 higher energy efficiency than alkaline electrolysis coupled with nuclear power. With the 269 exception of the SDE and the bayonet reactor, only proven, well-understood process technology 270 is used that can be accurately characterized with process models. Furthermore, development of 271 the SDE and the bayonet has advanced to the point where their performance targets appear to be 272 attainable. This gives confidence in the validity of the predicted performance for the HyS cycle. 
The design of the $750^{\circ} \mathrm{C}$ ROT flowsheet represents a departure from previous design

274 philosophy in several respects. The pressure differential between the secondary helium coolant

275 and the process fluid, for example, had always been kept to a minimum in order to allow the

276 smallest possible wall thickness for good heat transfer. Given the 40- to 90-bar secondary helium

277 coolant pressure range of the various HTGR options being considered for NGNP, this meant the

278 bayonet would be operated at 40- to 90-bar pressures as well. Lowering the ROT, however,

279 forced a reconsideration of this convention because of the shift in equilibrium conversion. The

280 combination of low temperature and high pressure would have had too negative an impact on the

281 high-temperature (endothermic) decomposition reaction in the bayonet. Moreover, an earlier

282 pinch analysis of the bayonet showed that for ROT below $875^{\circ} \mathrm{C}$, the high-temperature heat

283 requirement was minimized by operating at the lowest possible pressure [17]. With that in mind,

284 the process pressure was dropped to 12 bar, which was typical for older sulfuric acid

285 decomposition process designs (e.g. Öztürk et al. [25]). Under the bayonet concept, the high

286 pressure (40-90 bar, depending on the NGNP heat source design) would be on the outside

287 (helium side), putting the silicon carbide walls in compression, for which they should be well-

288 suited. Contamination of high-pressure helium with low-pressure sulfuric acid in the event of a

289 leak or failed seal would also be rendered highly unlikely. Consequently, there shouldn't be any

290 real barrier to operating the bayonet reactor at a significantly lower pressure than the helium heat

291 transfer medium.

292 The direct contact exchange/quench column is another departure from previous design

293 philosophy. Boiling sulfuric acid is highly corrosive, especially at temperatures in excess of 100-

$294150^{\circ} \mathrm{C}$, so any operation that entailed such conditions had been eschewed. However, the $\mathrm{H}_{2} \mathrm{SO}_{4-}$

$295 \mathrm{SO}_{3}-\mathrm{H}_{2} \mathrm{O}$ vapor-liquid equilibrium is highly favorable for trapping unreacted $\mathrm{H}_{2} \mathrm{SO}_{4}$ and $\mathrm{SO}_{3}$ in 
296 the liquid phase, and it was necessary to take advantage of this in order to overcome the lower

297 conversion resulting from lower temperature operation. Consequently, the temperature at the

298 bottom of the vacuum column was increased by about $50^{\circ} \mathrm{C}$ and a quench column was added that

299 handles concentrated sulfuric acid in the $230-260^{\circ} \mathrm{C}$ range. Suitable materials of construction

300 will need to be identified to withstand this severe service.

301 Assuming that a sulfuric acid decomposition catalyst active in the $550-675^{\circ} \mathrm{C}$ range can

302 be developed, this design is a viable option for a HyS cycle process driven by an advanced

303 nuclear reactor heat source operating at $750^{\circ} \mathrm{C}$ ROT. The projected $39.9 \% \mathrm{HHV}$ efficiency is

304 significantly better than that for alkaline electrolysis at $36.2 \%$.

\section{Conclusions}

A HyS cycle process was developed for the massive production of hydrogen from nuclear energy as part of the NGNP program under the NHI. It uses a PEM SDE for the lowtemperature, electrochemical reaction step and a novel bayonet reactor for the high-temperature decomposition step. An early version previously published that assumed an HTGR ROT of

$311945^{\circ} \mathrm{C}$ was projected to have a net thermal efficiency of $41.7 \%$, HHV basis. Subsequent changes

312 in the NGNP program led to the need to accommodate significantly lower decomposition

313 temperatures. Several improvements to the process resulted from this effort.

314 If the $\mathrm{SDE}$ is operated at $65 \mathrm{wt} \% \mathrm{H}_{2} \mathrm{SO}_{4}$ and the $\mathrm{SO}_{2}$ conversion is increased to $50 \%$ by

315 using a PEM material that does not rely on high water content for its conductivity (such as acid-

316 doped PBI) instead of Nafion®, Aspen Plus flowsheet simulation indicates that all of the heat

317 needed to concentrate the bayonet reactor feed can be provided by recuperation from the SDE

318 and from the bayonet product stream. However, the $\mathrm{SO}_{2} / \mathrm{O}_{2}$ separation can no longer be achieved 
319 by selective $\mathrm{SO}_{2}$ absorption into the recycled water and acid using a single absorber column. The

320 addition of an absorber/stripper combination provides the necessary separation with a minimal

321 low-quality heat input. Net thermal efficiencies of $44.0 \%$ to $47.6 \%$, HHV basis have been

322 projected if the HTGR ROT is $950^{\circ} \mathrm{C}$.

323 For the $750^{\circ} \mathrm{C}$ ROT case, the lower decomposition temperature was accommodated by

324 dropping the bayonet pressure to 12 bar, raising the bayonet feed and outlet temperatures, adding

325 a direct contact exchange/quench column upstream, and increasing the vacuum column bottoms

326 concentration to $90 \mathrm{wt} \% \mathrm{H}_{2} \mathrm{SO}_{4}$. Although the minimum heating requirement for the bayonet

327 increased significantly, this was offset by an increase in the opportunity for heat recuperation

328 from the bayonet product that eliminated the need for any additional heat input for acid

329 concentration. A net thermal efficiency of $39.9 \%$, $\mathrm{HHV}$ basis is projected for a $750^{\circ} \mathrm{C} \mathrm{HTGR}$

330 ROT.

332 Acknowledgements

333 The author wishes to acknowledge the financial support of DOE-NE provided through

334 Idaho National Laboratory MPO 94714 (Battelle Energy Alliance, LLC) under direction from

335 Mr. M.W. "Mike” Patterson, as well as the encouragement of Dr. William A. Summers, who led

336 SRNL's HyS development effort under the NHI. Helpful interactions with Mr. Charles O.

337 Bolthrunis (Shaw Stone \& Webster), Prof. John W. Weidner (USC), and Dr. Edward J. Lahoda

338 (Westinghouse Electric Co.) are also gratefully acknowledged. SRNL is operated for the DOE's

339 Office of Environmental Management by Savannah River Nuclear Solutions, LLC under contract

340 number DE-A C09-08SR22470. 
[1] Sink CJ. An Overview of the U.S. Department of Energy's Research and Development Program on Hydrogen Production Using Nuclear Energy. Presentation, AIChE Spring National Meeting, Orlando, FL, United States, April 23-27, 2006. Available at: http://www.aiche-ned.org/conferences/aiche2006spring/session_51/AICHE2006spring51b-Sink.pdf. Accessed May 24, 2011.

[2] US Department of Energy, US Department of Transportation. Hydrogen Posture Plan: An Integrated Research, Development and Demonstration Plan. December 2006; Available at: http://www.hydrogen.energy.gov/pdfs/hydrogen_posture_plan_dec06.pdf. Accessed May 24, 2011.

[3] Summers WA. Hybrid Sulfur Thermochemical Cycle. 2009 DOE Hydrogen Program and Vehicle Technologies Program Annual Merit Review and Peer Evaluation Meeting, Arlington, VA, United States, May 18-22, 2009. Available at: http://www.hydrogen.energy.gov/pdfs/review09/pd_13 summers.pdf. Accessed May 24, 2011.

[4] Colon-Mercado HR, Elvington MC, Steimke JL, Steeper TJ, Herman DT, Gorensek MB, et al. Recent Advances in the Development of the Hybrid Sulfur Process for Hydrogen Production. Nuclear Energy and the Environment.ACS Symposium Series Vol 1046: American Chemical Society; 2010:141-154.

[5] Moore RC, Gelbard F, Parma EJ, Vernon ME, Lenard RX, Pickard PS. A LaboratoryScale Sulfuric Acid Decomposition Apparatus for Use in Hydrogen Production Cycles. Proceedings: International Topical Meeting on Safety and Technology of Nuclear Hydrogen Production, Control, and Management , Boston, MA, United States, June 2428, 2007. 2007:161-166.

[6] Gorensek MB, Summers WA. Hybrid sulfur flowsheets using PEM electrolysis and a bayonet decomposition reactor. International Journal of Hydrogen Energy. 2009;34(9):4097-4114.

[7] Review of DOE'S Nuclear Energy Research and Development Program. Washington, DC: National Research Council; 2008.

[8] Public Law 109-58 - Energy Policy Act of 2005, §Title VI - Nuclear Matters, Subtitle C Next Generation Nuclear Plant Project. 109th United States Congress. August 8, 2005.

[9] US Department of Energy, Office of Nuclear Energy. Next Generation Nuclear Plant Demonstration Project. February 15, 2011; Available at: http://www.ne.doe.gov/pdfFiles/factSheets/2012_NGNP_Factsheet_final.pdf. Accessed May 24, 2011.

[10] Brecher LE, Wu CK; Westinghouse Electric Corp., assignee. Electrolytic decomposition of water. US patent 3888750. June 10, 1975.

[11] Gorensek MB, Staser JA, Stanford TG, Weidner JW. A thermodynamic analysis of the $\mathrm{SO}_{2} / \mathrm{H}_{2} \mathrm{SO}_{4}$ system in $\mathrm{SO}_{2}$-depolarized electrolysis. International Journal of Hydrogen Energy. 2009;34(15):6089-6095.

[12] Gorensek MB, Summers WA. The hybrid sulfur cycle. In: Yan XL, Hino R, eds. Nuclear Hydrogen Production Handbook. Boca Raton, FL: CRC Press; 2011:499-545.

[13] Southworth FH, MacDonald PE, Harrell DJ, Shaber EL, Park CV, Holbrook MR, et al. The Next Generation Nuclear Plant (NGNP) Project. Proceedings of Global 2003, Atoms 
for Prosperity: Updating Eisenhower's Global Vision of Nuclear Energy; November 16 20, 2003; New Orleans, LA.

[14] Burchell T, Bratton RL, Wright RN, Wright J. Next Generation Nuclear Plant Materials Research and Development Program Plan. Idaho National Laboratory; INL/EXT-0611701, Rev. 4. September 2007.

[15] Collins JW. NGNP Risk Management through Assessing Technology Readiness Status. Idaho National Laboratory; INL/EXT-10-19197. August 2010.

[16] Knoche KF, Funk JE. Entropy production, efficiency, and economics in the thermochemical generation of synthetic fuels: I. The hybrid sulfuric acid process. International Journal of Hydrogen Energy. 1977;2(4):377-385.

[17] Gorensek MB, Edwards TB. Energy Efficiency Limits for a Recuperative Bayonet Sulfuric Acid Decomposition Reactor for Sulfur Cycle Thermochemical Hydrogen Production. Industrial \& Engineering Chemistry Research. 2009;48(15):7232-7245.

[18] The Hydrogen Economy: Opportunities, Costs, Barriers, and R\&D Needs. Washington, DC: National Academy of Engineering (NAE); 2004.

[19] Gorensek MB, Summers WA, Bolthrunis CO, Lahoda EJ, Allen DT, Greyvenstein R. Hybrid Sulfur Process Reference Design and Cost Analysis. Savannah River National Laboratory; SRNL-L1200-2008-00002. June 12, 2009.

[20] Staser JA, Gorensek MB, Weidner JW. Quantifying Individual Potential Contributions of the Hybrid Sulfur Electrolyzer. Journal of The Electrochemical Society. 2010;157(6):B952-B958.

[21] Wainright JS, Wang JT, Weng D, Savinell RF, Litt M. Acid-Doped Polybenzimidazoles: A New Polymer Electrolyte. Journal of The Electrochemical Society. 1995;142(7):L121L123.

[22] Aspen Plus [computer program]. Version 7.1 (23.0). Burlington, MA, United States: Aspen Technology, Inc.; 1981-2009.

[23] Aspen Energy Analyzer [computer program]. Version 7.1 (23.0). Burlington, MA, United States: Aspen Technology, Inc.; 1995-2009.

[24] McKellar MG. An Analysis of the Effect of Reactor Outlet Temperature of a High Temperature Reactor on Electric Power Generation, Hydrogen Production, and Process Heat. Idaho National Laboratory; TEV- 981. September 14, 2010.

[25] Öztürk IT, Hammache A, Bilgen E. An improved process for $\mathrm{H}_{2} \mathrm{SO}_{4}$ decomposition step of the sulfur-iodine cycle. Energy Conversion and Management. 1995;36(1):11-21. 


\section{List of Figure Captions}

423

424

425

426

427

428

429

430

431

432

Figure 1 The hybrid sulfur (HyS) cycle.

Figure 2 SRNL PEM SO$~_{2}$-depolarized electrolyzer (SDE) schematic. The SRNL design features a recirculating anolyte saturated with dissolved $\mathrm{SO}_{2}$.

Figure 3 SNL high-temperature bayonet $\mathrm{H}_{2} \mathrm{SO}_{4}$ decomposer schematic. Insulated base where fluid connections are made remains cool. Silicon carbide material of construction can withstand boiling sulfuric acid at high temperatures.

Figure 4 Schematic diagram of heat transfer from nuclear heat source to bayonet reactor.

Figure $5950^{\circ} \mathrm{C}$ ROT HyS process flowsheet.

Figure 6 Recuperation detail for $950^{\circ} \mathrm{C}$ ROT HyS process flowsheet.

Figure 7 Pinch diagram for RX-01 Bayonet Reactor in Figure 5 (950 ${ }^{\circ} \mathrm{C}$ ROT).

Figure 8 Hot He utility composite curve for RX-01 Bayonet Reactor in Figure $5\left(950^{\circ} \mathrm{C}\right.$ ROT).

Figure $9750^{\circ} \mathrm{C}$ ROT HyS process flowsheet.

Figure 10 Pinch diagram for RX-01 Bayonet Reactor in Figure $9\left(750^{\circ} \mathrm{C}\right.$ ROT). 
458 Figure 11 Hot He utility composite curve for RX-01 Bayonet Reactor in Figure $9\left(750^{\circ} \mathrm{C} \mathrm{ROT}\right)$. 459 
Hybrid sulfur cycle flowsheets for $\mathrm{H}_{2}$ production using HTGRs

page 22 of 22

460

461

462

463 Table 1 Design bases for the $950^{\circ} \mathrm{C}$ and $750^{\circ} \mathrm{C}$ ROT HyS process flowsheets.

464

465

466

467

468

469

470

471

472 Table $4750^{\circ} \mathrm{C}$ ROT HyS process flowsheet stream table.

473

474

475

\section{List of Table Captions}

Table $2950^{\circ} \mathrm{C}$ ROT HyS process flowsheet stream table.

Table $3950^{\circ} \mathrm{C}$ ROT HyS process flowsheet energy utilization summary.

Table $5750^{\circ} \mathrm{C}$ ROT HyS process flowsheet energy utilization summary. 
Figure 1

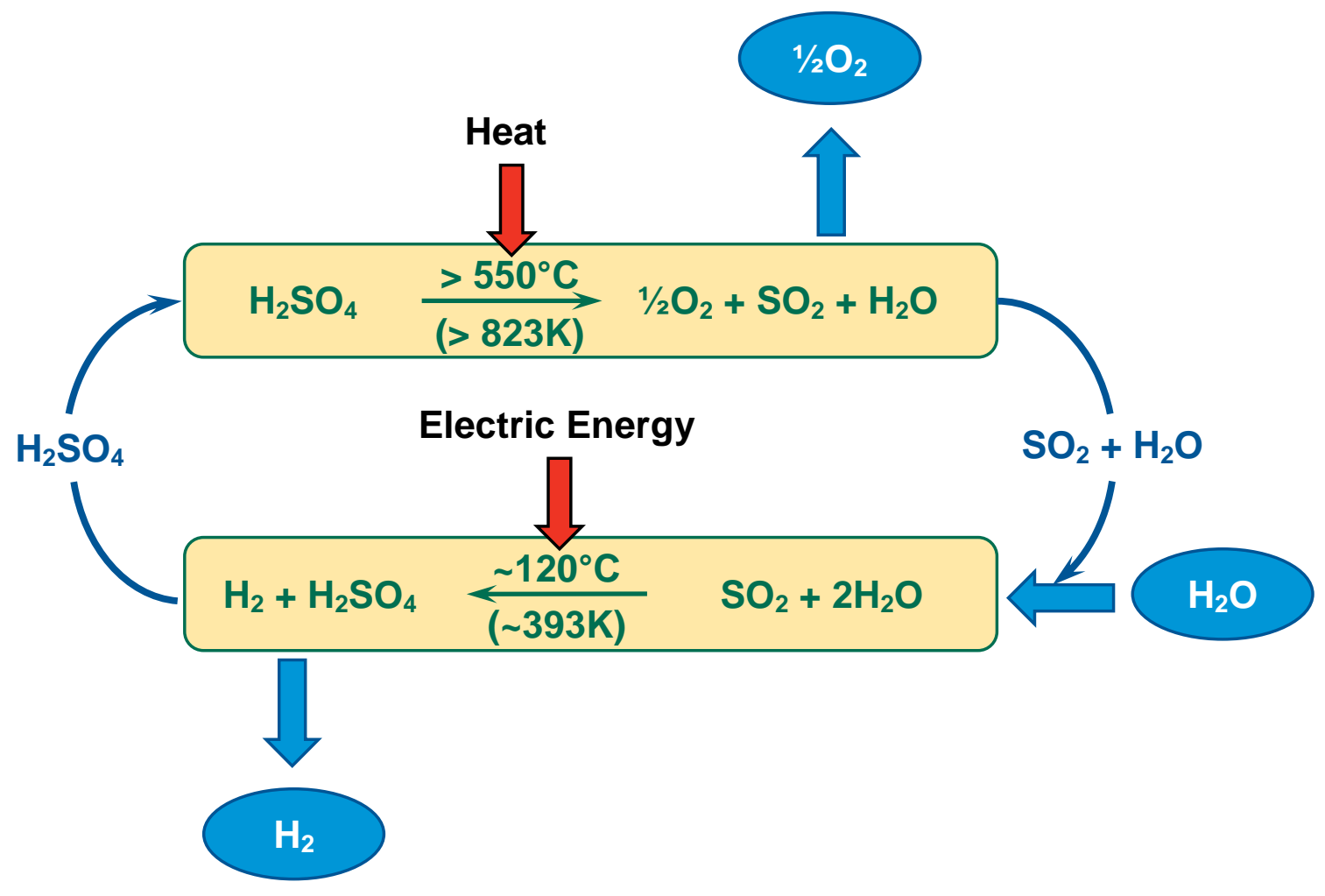

Figure 1 


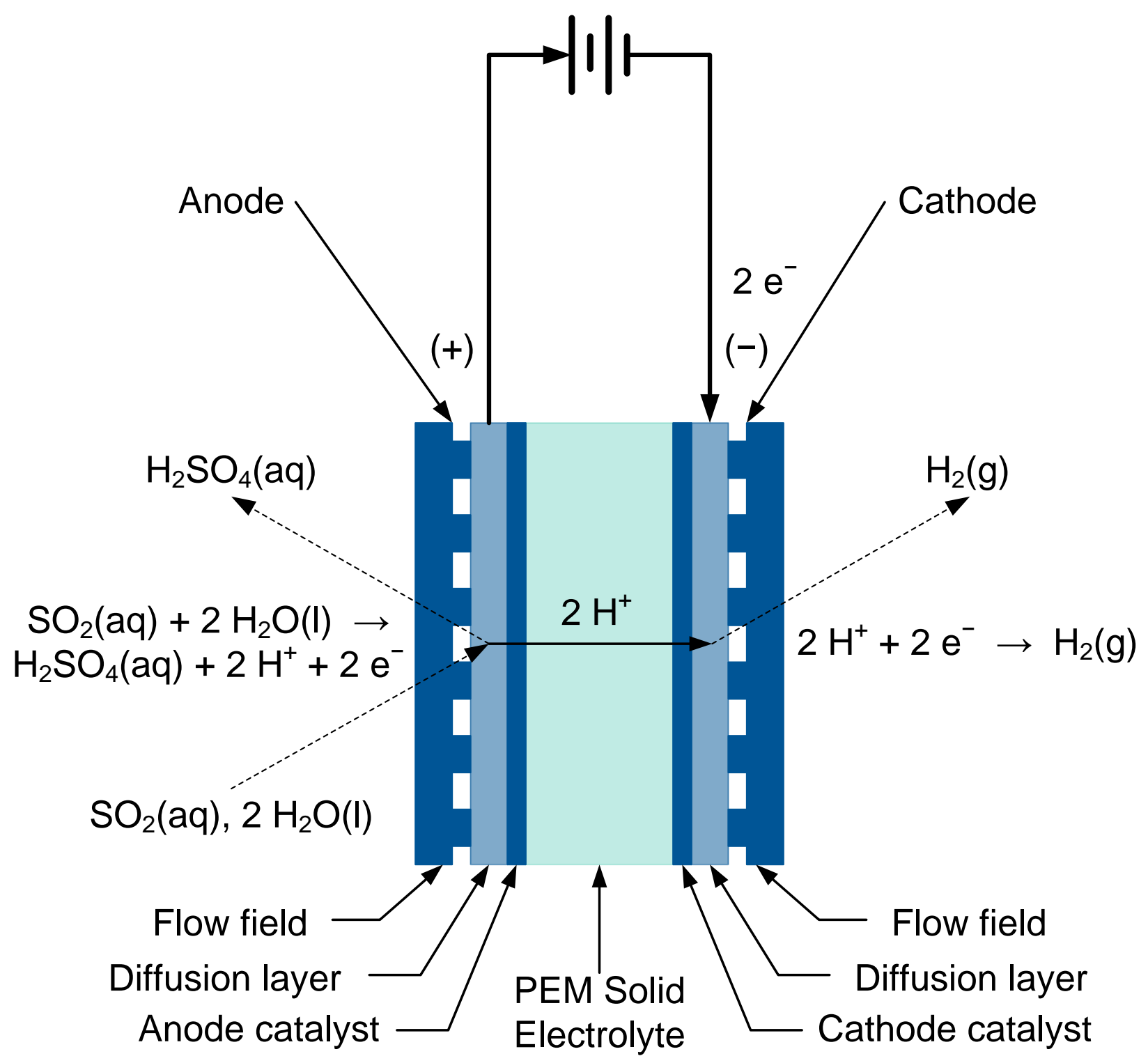

Figure 2 
Figure 3

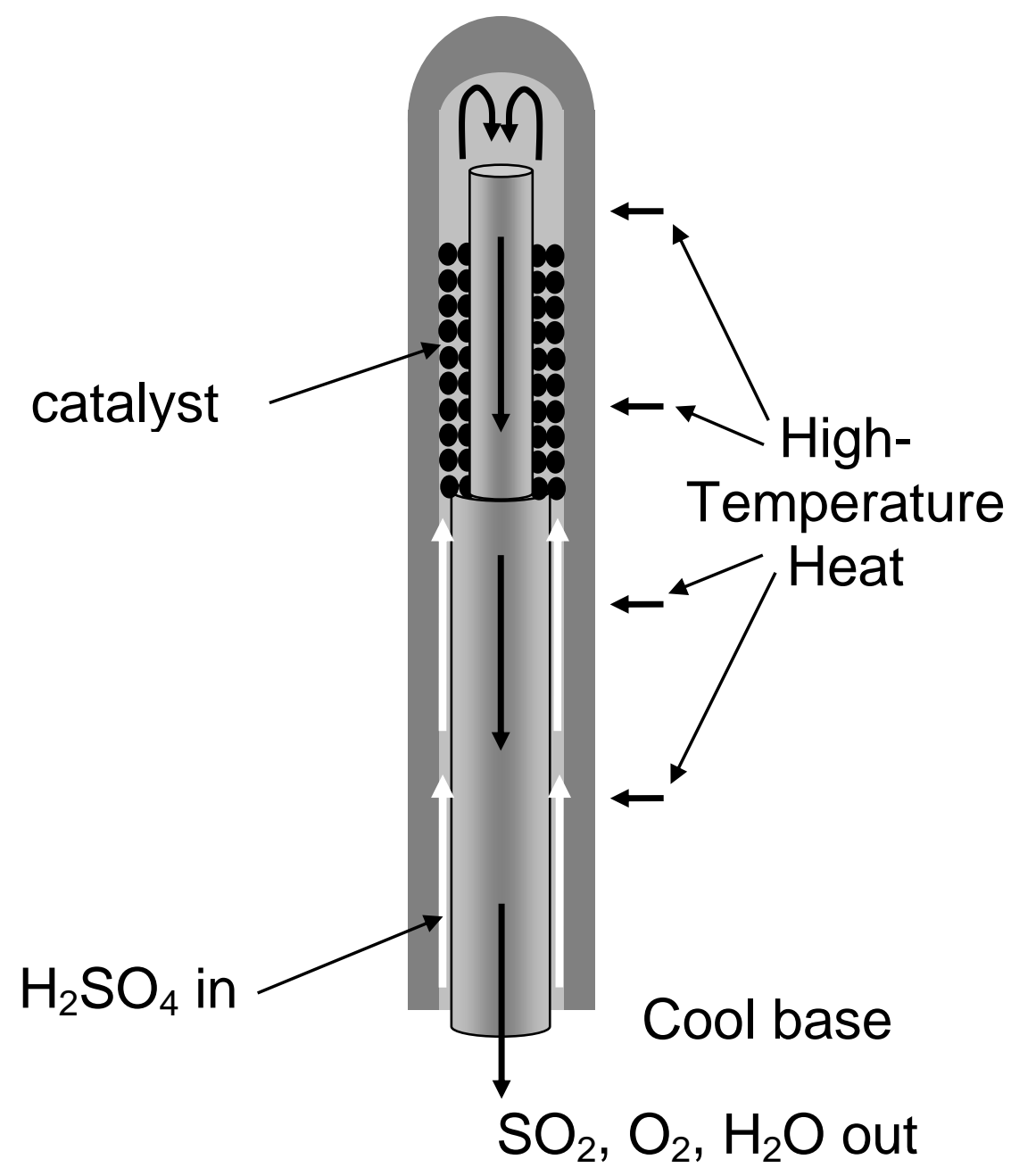

Figure 3 


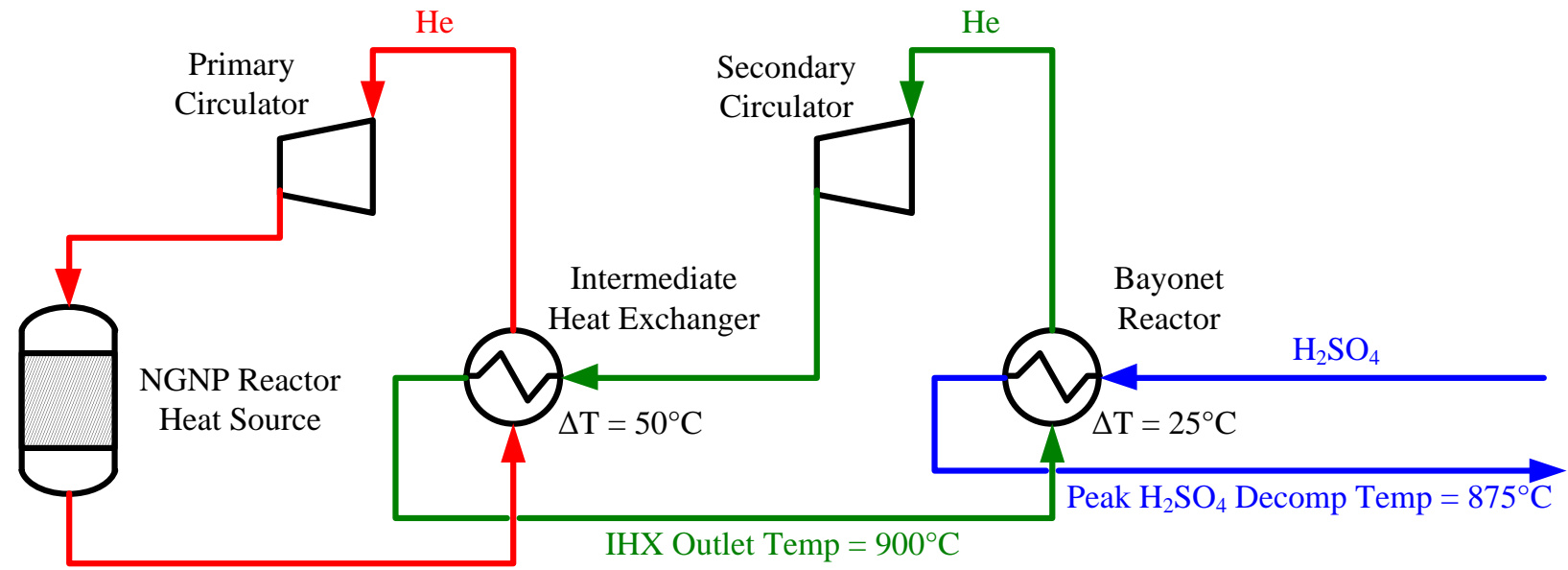

Reactor Outlet Temp $=950^{\circ} \mathrm{C}$

Figure 4 


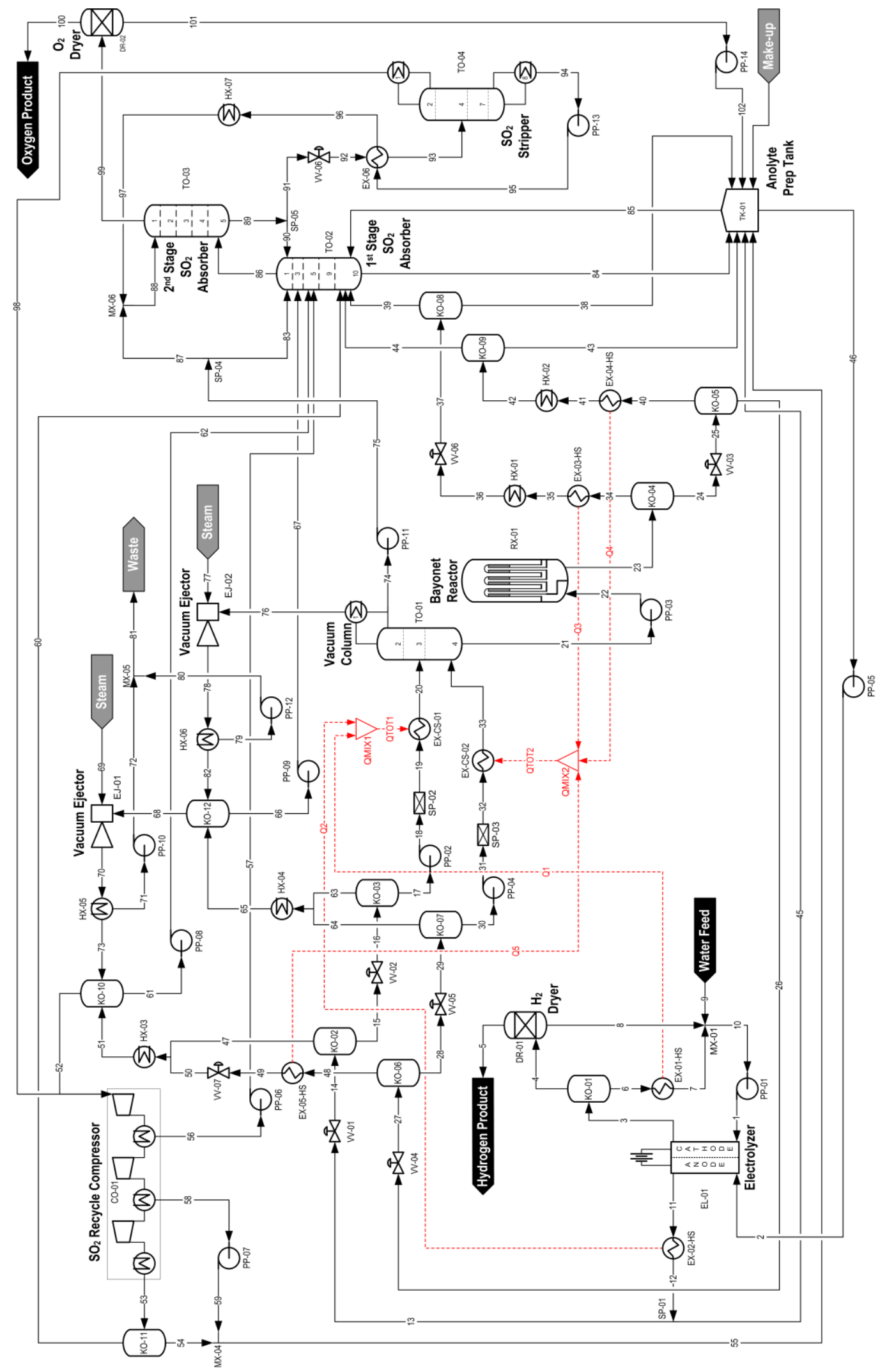

Figure 5 


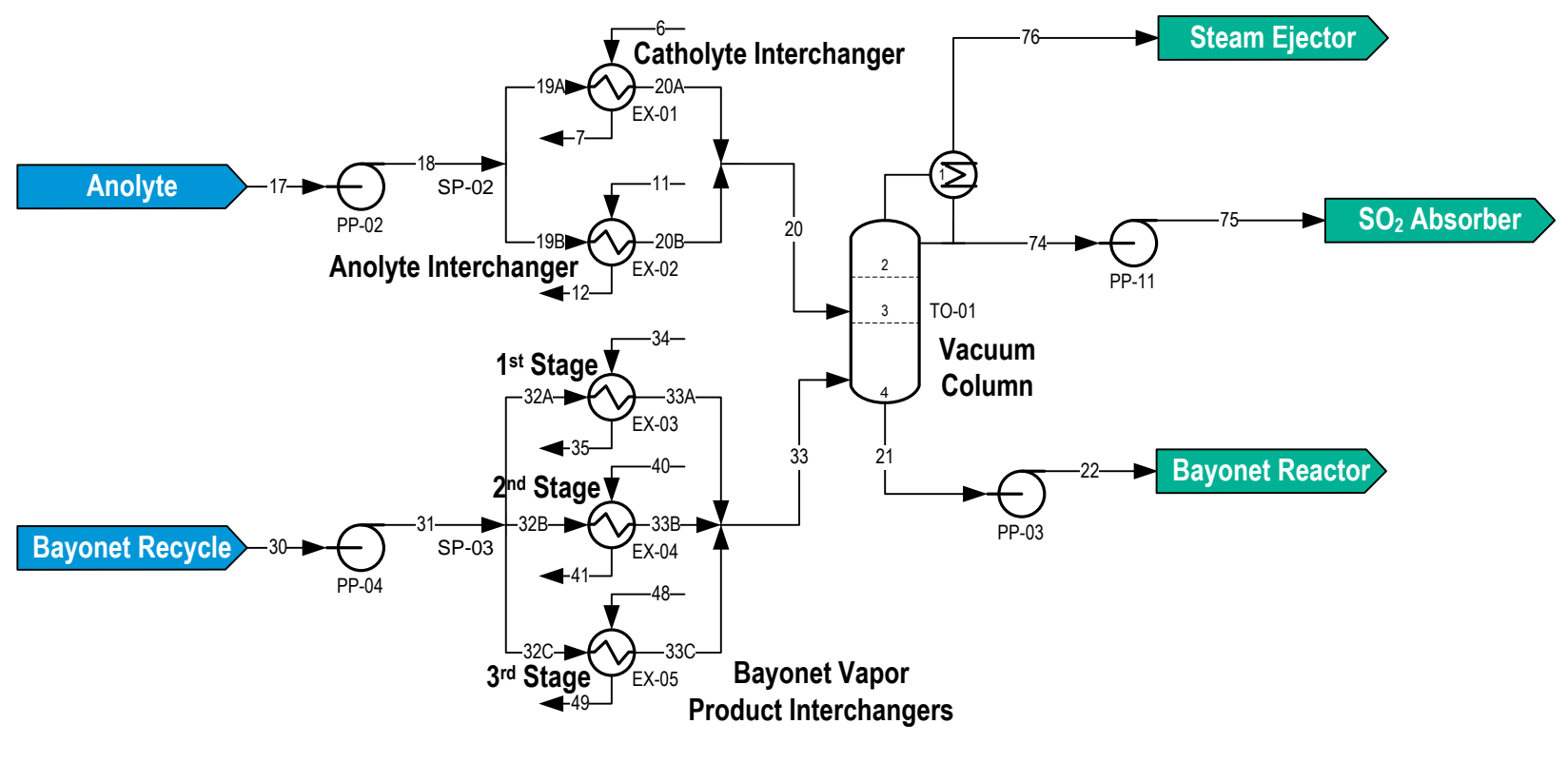

Figure 6

Anol

. 


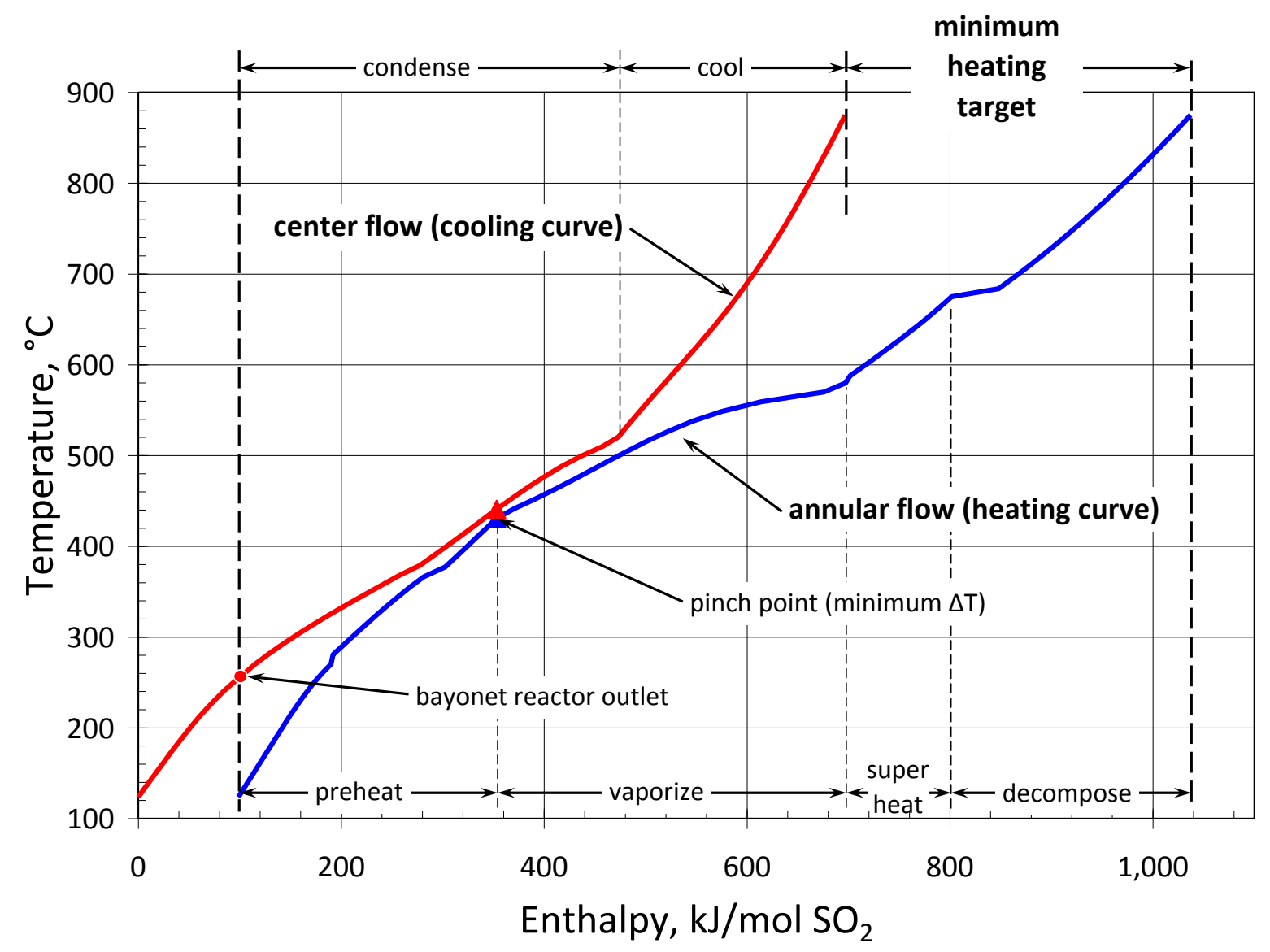

Figure 7 


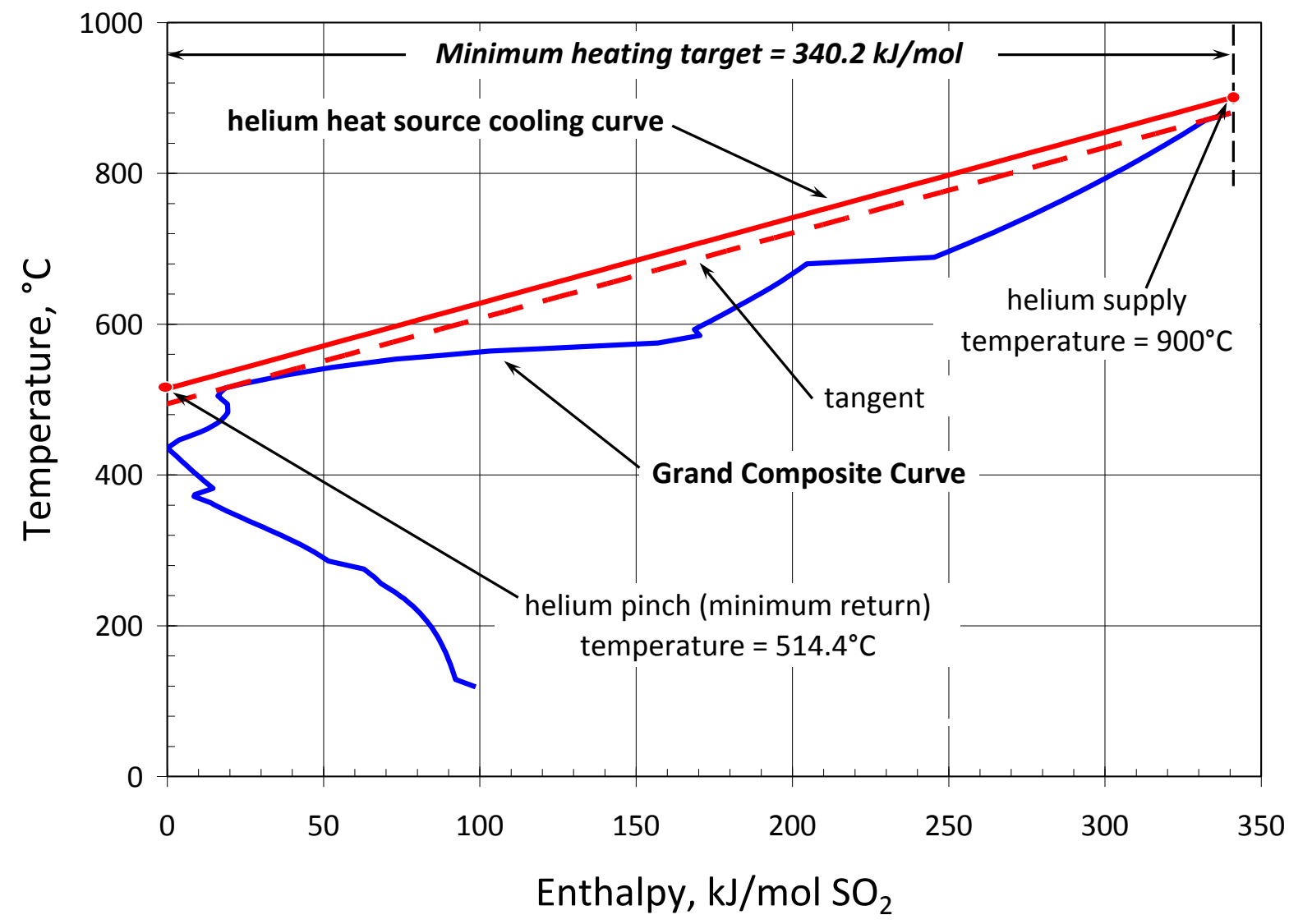

Figure 8 


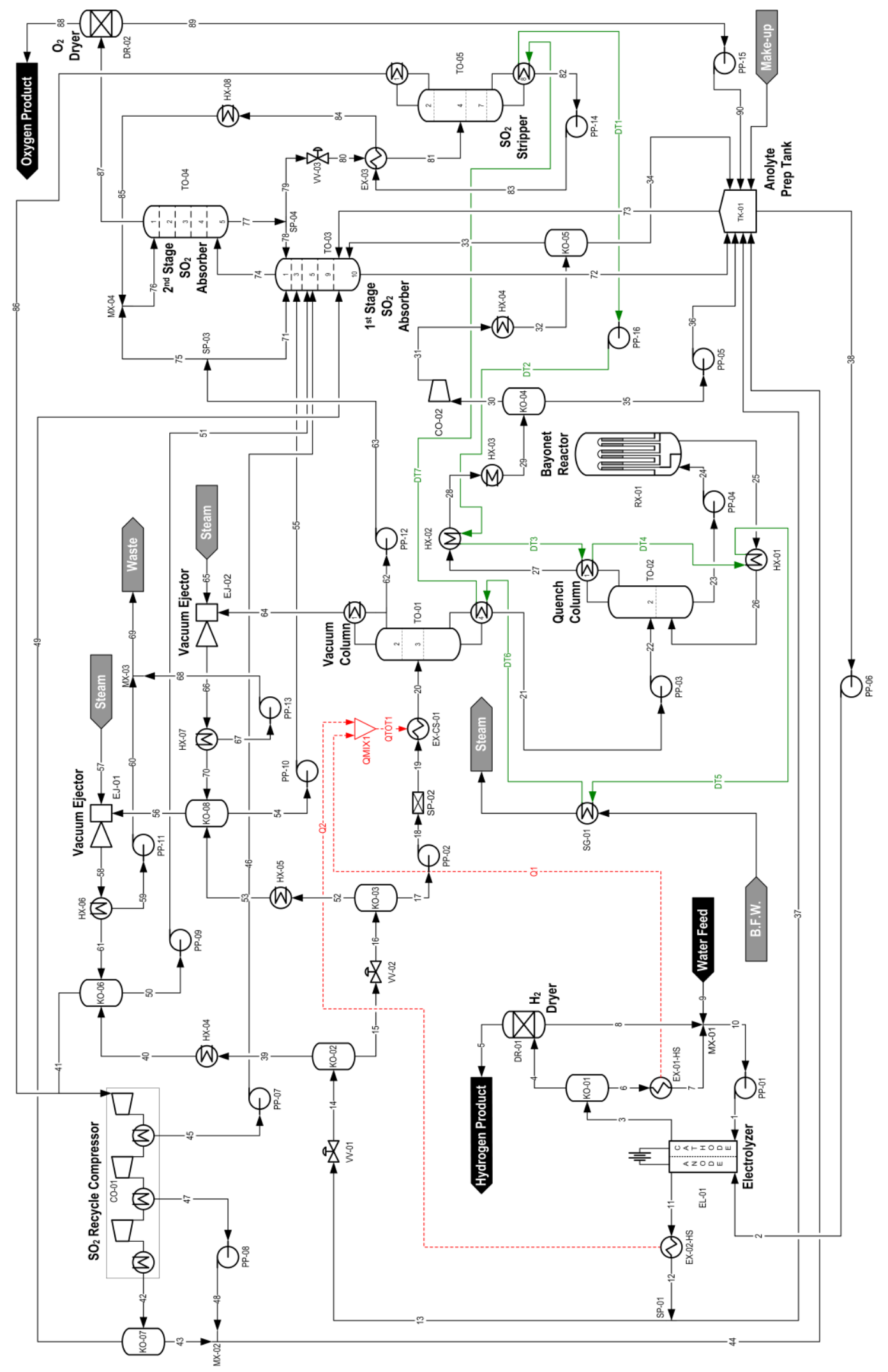

Figure 9 


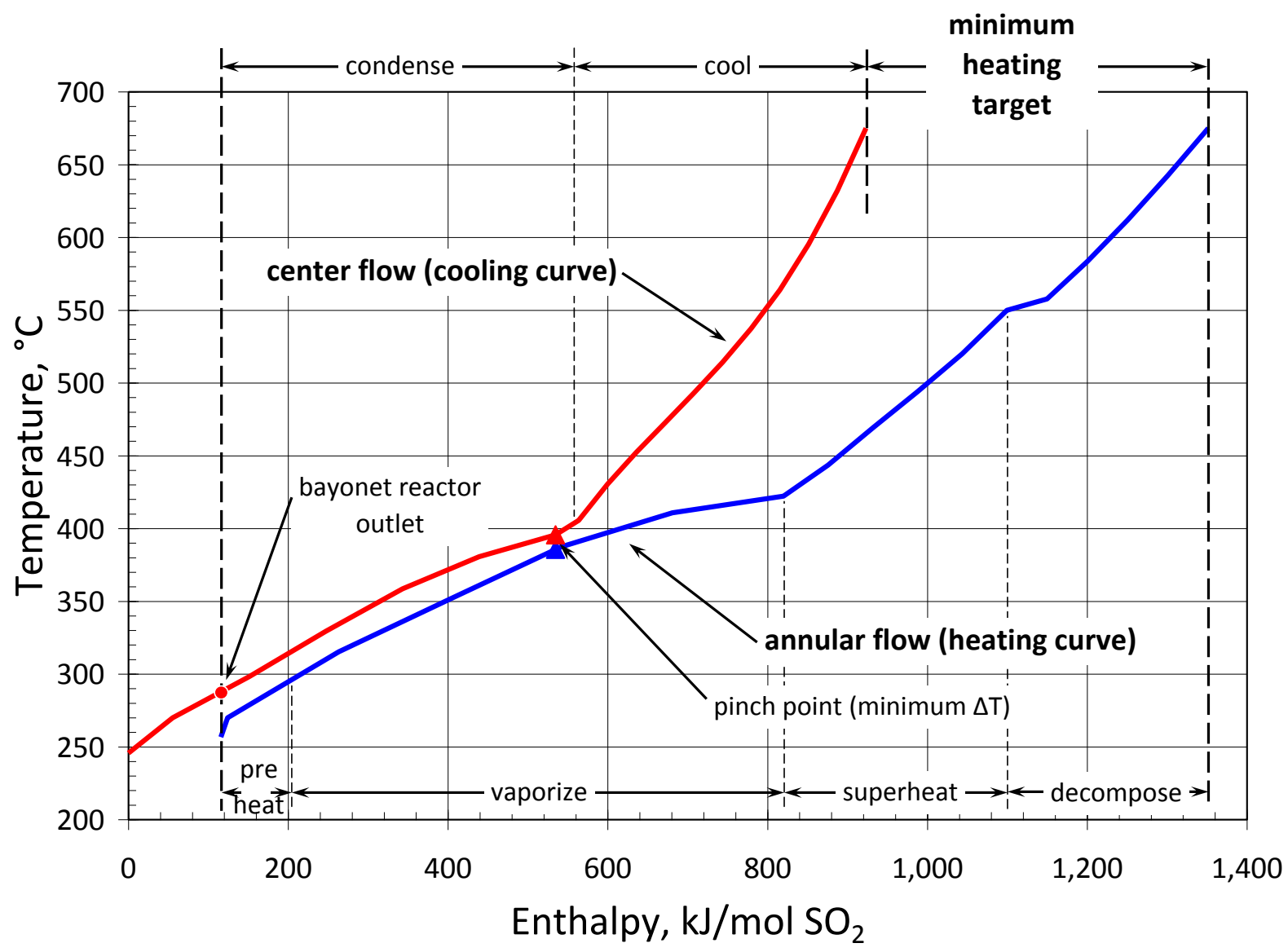

Figure 10 


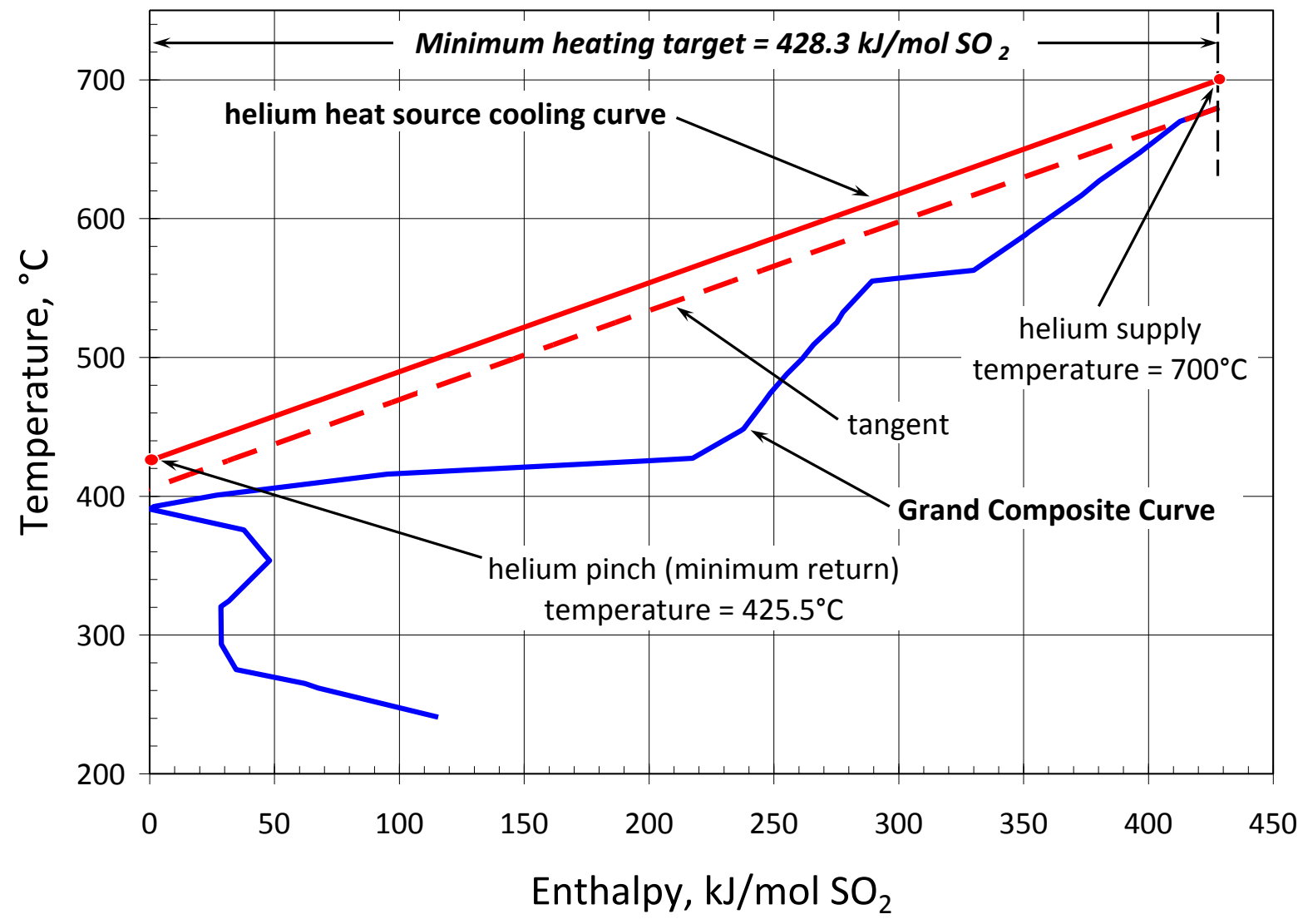

Figure 11 
Table 1 Design bases for the $950^{\circ} \mathrm{C}$ and $750^{\circ} \mathrm{C}$ ROT HyS process flowsheets.

\begin{tabular}{|c|c|c|c|}
\hline \multirow[b]{2}{*}{ Nominal Hydrogen Production Rate } & $950^{\circ} \mathrm{C}$ ROT Case & \multicolumn{2}{|c|}{$750^{\circ} \mathrm{C}$ ROT Case } \\
\hline & $1 \mathrm{kmol} / \mathrm{sec}$ & 1 & $\mathrm{kmol} / \mathrm{sec}$ \\
\hline Hydrogen Product Temperature & $48{ }^{\circ} \mathrm{C}$ & 48 & ${ }^{\circ} \mathrm{C}$ \\
\hline Hydrogen Product Pressure & 20 bar & 20 & bar \\
\hline Oxygen Co-product Production Rate & $0.5 \mathrm{kmol} / \mathrm{sec}$ & 0.5 & $\mathrm{kmol} / \mathrm{sec}$ \\
\hline Oxygen Co-product Temperature & $48{ }^{\circ} \mathrm{C}$ & 48 & ${ }^{\circ} \mathrm{C}$ \\
\hline Oxygen Co-product Pressure & 20 bar & 20 & bar \\
\hline \multicolumn{4}{|l|}{ HyS SDE (EL-01) Operating Assumptions } \\
\hline Operating Temperature & $120{ }^{\circ} \mathrm{C}$ & 120 & ${ }^{\circ} \mathrm{C}$ \\
\hline Operating Pressure & 22 bar & 22 & bar \\
\hline Operating Potential & $0.6 \mathrm{~V}$ & 0.6 & $\mathrm{~V}$ \\
\hline $\mathrm{SO}_{2}$ Concentration in Anolyte Feed & $11.8 \mathrm{wt} \%$ & 11.8 & $\mathrm{wt} \%$ \\
\hline Acid Product Concentration (Anode) & $65 \mathrm{wt} \%$ & 65 & $\mathrm{wt} \%$ \\
\hline Conversion (per pass) & $50 \%$ & 50 & $\%$ \\
\hline Cathode Pressure Drop & 1 bar & 1 & bar \\
\hline Water-swept Cathode & & & \\
\hline Water Flux (Cathode to Anode) & $1 \mathrm{kmol} / \mathrm{sec}$ & 1 & $\mathrm{kmol} / \mathrm{sec}$ \\
\hline Anode Pressure Drop & 1 bar & 1 & bar \\
\hline \multirow{2}{*}{\multicolumn{4}{|c|}{$\begin{array}{l}\text { Bayonet Reactor (RX-01) Operating } \\
\text { Assumptions }\end{array}$}} \\
\hline & & & \\
\hline Feed Pressure & 86 bar & 12.7 & bar \\
\hline Pressure Drop & 2 bar & 1 & bar \\
\hline Feed Concentration (Quench Column) & N/A & 90 & wt $\%$ \\
\hline Feed Concentration (Bayonet Reactor) & $75 \mathrm{wt} \%$ & 76.1 & $\mathrm{wt} \%$ \\
\hline Catalyst Bed Inlet Temperature & $675{ }^{\circ} \mathrm{C}$ & 550 & ${ }^{\circ} \mathrm{C}$ \\
\hline Catalyst Bed Exit Temperature & $875{ }^{\circ} \mathrm{C}$ & 675 & ${ }^{\circ} \mathrm{C}$ \\
\hline Minimum $\Delta \mathrm{T}$ (Helium to Process) & $25{ }^{\circ} \mathrm{C}$ & 25 & ${ }^{\circ} \mathrm{C}$ \\
\hline Minimum $\Delta \mathrm{T}$ (Internal Recuperation) & $10{ }^{\circ} \mathrm{C}$ & 10 & ${ }^{\circ} \mathrm{C}$ \\
\hline \multicolumn{4}{|l|}{ Equilibrium Attained in Catalyst Bed } \\
\hline \multicolumn{4}{|l|}{ HTGR Operating Assumptions } \\
\hline Reactor Outlet Temperature & $950{ }^{\circ} \mathrm{C}$ & 750 & ${ }^{\circ} \mathrm{C}$ \\
\hline He Coolant Supply Temperature & $900{ }^{\circ} \mathrm{C}$ & 700 & ${ }^{\circ} \mathrm{C}$ \\
\hline \multicolumn{4}{|l|}{ Vacuum Column (TO-01) Operating Conditions } \\
\hline Overhead Pressure & 0.11 bar & 0.11 & bar \\
\hline Condenser Temperature & $44.1{ }^{\circ} \mathrm{C}$ & 44.6 & ${ }^{\circ} \mathrm{C}$ \\
\hline Bottoms $\mathrm{H}_{2} \mathrm{SO}_{4}$ Concentration & $75 \mathrm{wt} \%$ & 90 & $\mathrm{wt} \%$ \\
\hline Column Pressure Drop & 0.02 bar & 0.02 & bar \\
\hline Quench Column Operating Conditions & N/A & $(\mathrm{TO}$ & $-02)$ \\
\hline
\end{tabular}


Overhead Pressure

Condenser Temperature

$1^{\text {st }}$ Stage $\mathrm{SO}_{2}$ Absorber Operating Conditions

Overhead Pressure

Column Pressure Drop

$2^{\text {nd }}$ Stage $\mathrm{SO}_{2}$ Absorber Operating Conditions

Overhead Pressure

Column Pressure Drop

$\mathrm{H}_{2} \mathrm{O} / \mathrm{O}_{2}$ Molar Feed Ratio

$\mathrm{SO}_{2}$ Stripper Operating Conditions

Overhead Pressure

(Partial-Vapor) Condenser Temperature

Bottoms Product $\mathrm{SO}_{2}$ Concentration*

Column Pressure Drop

Electric Power Generation Efficiency $\left(\mathrm{kJ}_{\mathrm{e}} / \mathrm{kJ}_{\mathrm{th}}\right)$
(TO-02)

20.9 bar

0.1 bar

(TO-03)

20.8 bar

0.1 bar

38

(TO-04)

1 bar

$48{ }^{\circ} \mathrm{C}$

$1.8 \times 10^{-3}$ wt $\%$

0.1 bar

$48 \%$
11.1 bar $235{ }^{\circ} \mathrm{C}$

(TO-03)

20.9 bar

0.1 bar

(TO-04)

20.8 bar

0.1 bar

40

(TO-05)

1 bar

$48{ }^{\circ} \mathrm{C}$

$1.4 \times 10^{-3} \quad \mathrm{wt} \%$

0.1 bar

$45 \%$

* Controlled to achieve 1 ppm $\mathrm{SO}_{2}$ in $2^{\text {nd }}$ Stage $\mathrm{SO}_{2}$ Absorber overhead product 
Table $2950^{\circ} \mathrm{C}$ ROT HyS process flowsheet stream table.

\begin{tabular}{|c|c|c|c|c|c|c|c|c|c|c|}
\hline \multirow{2}{*}{$\begin{array}{c}\text { Stream } \\
\text { ID }\end{array}$} & \multicolumn{6}{|c|}{ Molar flow rates, $\mathrm{kmol} / \mathrm{sec}^{*}$} & \multicolumn{2}{|c|}{ Temperature, } & \multirow{2}{*}{$\begin{array}{c}\text { Pressure, } \\
\text { bar }\end{array}$} & \multirow[t]{2}{*}{ Phase } \\
\hline & $\mathrm{H}_{2} \mathrm{O}$ & $\mathrm{H}_{2} \mathrm{SO}_{4}$ & $\mathrm{SO}_{2}$ & $\mathrm{O}_{2}$ & $\mathrm{H}_{2}$ & Total & ${ }^{\circ} \mathrm{C}$ & $\mathrm{K}$ & & \\
\hline 1 & 138.00 & 0 & 0 & 0 & 0.0422 & 138.04 & 115.45 & 388.60 & 22.750 & $\mathrm{~L}$ \\
\hline 2 & 21.834 & 5.7659 & 2 & 2E-05 & 0 & 29.600 & 112.59 & 385.74 & 22.750 & $\mathrm{~L}$ \\
\hline 3 & 137.00 & 0 & 0 & 0 & 1.0422 & 138.04 & 120.00 & 393.15 & 21.750 & $\mathrm{~L}+\mathrm{V}$ \\
\hline 4 & 0.10347 & 0 & 0 & 0 & 1 & 1.1035 & 120.00 & 393.15 & 21.750 & $\mathrm{~V}$ \\
\hline 5 & 0 & 0 & 0 & 0 & 1 & 1 & 48.00 & 321.15 & 20.000 & $\mathrm{~V}$ \\
\hline 6 & 136.90 & 0 & 0 & 0 & 0.0422 & 136.94 & 120.00 & 393.15 & 21.750 & $\mathrm{~L}$ \\
\hline 7 & 136.90 & 0 & 0 & 0 & 0.0422 & 136.94 & 116.00 & 389.15 & 21.000 & $\mathrm{~L}+\mathrm{V}$ \\
\hline 8 & 0.10347 & 0 & 0 & 0 & 0 & 0.10347 & 48.00 & 321.15 & 20.000 & $\mathrm{~L}$ \\
\hline 9 & 1 & 0 & 0 & 0 & 0 & 1 & 40.00 & 313.15 & 20.000 & $\mathrm{~L}$ \\
\hline 10 & 138.00 & 0 & 0 & 0 & 0.0422 & 138.04 & 115.42 & 388.57 & 20.000 & $\mathrm{~L}+\mathrm{V}$ \\
\hline 11 & 20.834 & 6.7659 & 1 & 2E-05 & 0 & 28.600 & 120.00 & 393.15 & 21.750 & $\mathrm{~L}$ \\
\hline 12 & 20.834 & 6.7659 & 1 & $2 \mathrm{E}-05$ & 0 & 28.600 & 116.00 & 389.15 & 21.000 & $\mathrm{~L}$ \\
\hline 13 & 3.0821 & 1.0009 & 0.14794 & $2.9 \mathrm{E}-06$ & 0 & 4.2309 & 116.00 & 389.15 & 21.000 & $\mathrm{~L}$ \\
\hline 14 & 3.0821 & 1.0009 & 0.14794 & 2.9E-06 & 0 & 4.2309 & 105.57 & 378.72 & 1.013 & $\mathrm{~L}+\mathrm{V}$ \\
\hline 15 & 3.0382 & 1.0009 & 0.00863 & $2.2 \mathrm{E}-09$ & 0 & 4.0477 & 105.57 & 378.72 & 1.013 & $\mathrm{~L}$ \\
\hline 16 & 3.0382 & 1.0009 & 0.00863 & 2.2E-09 & 0 & 4.0477 & 103.47 & 376.62 & 0.330 & $\mathrm{~L}+\mathrm{V}$ \\
\hline 17 & 3.0234 & 1.0009 & 0.00126 & 0 & 0 & 4.0256 & 103.47 & 376.62 & 0.330 & $\mathrm{~L}$ \\
\hline 18 & 3.0234 & 1.0009 & 0.00126 & 0 & 0 & 4.0256 & 103.47 & 376.62 & 0.430 & $\mathrm{~L}$ \\
\hline 19 & 3.0234 & 1.0009 & 0.00126 & 0 & 0 & 4.0256 & 103.47 & 376.62 & 0.330 & $\mathrm{~L}+\mathrm{V}$ \\
\hline 20 & 3.0234 & 1.0009 & 0.00126 & 0 & 0 & 4.0256 & 115.40 & 388.55 & 0.130 & $\mathrm{~L}+\mathrm{V}$ \\
\hline 21 & 3.7568 & 2.0702 & $1.5 \mathrm{E}-08$ & 0 & 0 & 5.8270 & 122.86 & 396.01 & 0.130 & $\mathrm{~L}$ \\
\hline 22 & 3.7568 & 2.0702 & $1.5 \mathrm{E}-08$ & 0 & 0 & 5.8270 & 123.62 & 396.77 & 86.000 & $\mathrm{~L}$ \\
\hline 23 & 4.7577 & 1.0693 & 1.0009 & 0.50046 & 0 & 7.3283 & 254.50 & 527.65 & 84.000 & $\mathrm{~L}+\mathrm{V}$ \\
\hline 24 & 4.2803 & 1.0693 & 0.22812 & 0.00805 & 0 & 5.5857 & 254.50 & 527.65 & 84.000 & $\mathrm{~L}$ \\
\hline 25 & 4.2803 & 1.0693 & 0.22812 & 0.00805 & 0 & 5.5857 & 235.12 & 508.27 & 22.200 & $\mathrm{~L}+\mathrm{V}$ \\
\hline 26 & 4.0273 & 1.0693 & 0.05077 & 9.8E-05 & 0 & 5.1474 & 235.12 & 508.27 & 22.200 & $\mathrm{~L}$ \\
\hline 27 & 4.0273 & 1.0693 & 0.05077 & $9.8 \mathrm{E}-05$ & 0 & 5.1474 & 187.36 & 460.51 & 4.000 & $\mathrm{~L}+\mathrm{V}$ \\
\hline 28 & 3.5270 & 1.0693 & 0.00205 & 1.1E-07 & 0 & 4.5983 & 187.36 & 460.51 & 4.000 & $\mathrm{~L}$ \\
\hline 29 & 3.5270 & 1.0693 & 0.00205 & 1.1E-07 & 0 & 4.5983 & 120.33 & 393.48 & 0.330 & $\mathrm{~L}+\mathrm{V}$ \\
\hline 30 & 2.8790 & 1.0693 & 9.2E-06 & 0 & 0 & 3.9483 & 120.33 & 393.48 & 0.330 & $\mathrm{~L}$ \\
\hline 31 & 2.8790 & 1.0693 & 9.2E-06 & 0 & 0 & 3.9483 & 120.33 & 393.48 & 0.430 & $\mathrm{~L}$ \\
\hline 32 & 2.8790 & 1.0693 & 9.2E-06 & 0 & 0 & 3.9483 & 120.33 & 393.48 & 0.330 & $\mathrm{~L}+\mathrm{V}$ \\
\hline 33 & 2.8790 & 1.0693 & 9.2E-06 & 0 & 0 & 3.9483 & 125.53 & 398.68 & 0.130 & $\mathrm{~L}+\mathrm{V}$ \\
\hline 34 & 0.47738 & $5.5 \mathrm{E}-06$ & 0.77280 & 0.49241 & 0 & 1.7426 & 254.50 & 527.65 & 84.000 & V \\
\hline 35 & 0.47738 & $5.5 \mathrm{E}-06$ & 0.77280 & 0.49241 & 0 & 1.7426 & 130.33 & 403.48 & 83.400 & $\mathrm{~L}+\mathrm{V}$ \\
\hline 36 & 0.47738 & $5.5 \mathrm{E}-06$ & 0.77280 & 0.49241 & 0 & 1.7426 & 48.00 & 321.15 & 82.800 & $\mathrm{~L}+\mathrm{V}$ \\
\hline 37 & 0.47738 & $5.5 \mathrm{E}-06$ & 0.77280 & 0.49241 & 0 & 1.7426 & 30.91 & 304.06 & 21.000 & $\mathrm{~L}+\mathrm{V}$ \\
\hline 38 & 0.47566 & $5.5 \mathrm{E}-06$ & 0.61477 & 0.00045 & 0 & 1.0909 & 30.91 & 304.06 & 21.000 & $\mathrm{~L}$ \\
\hline 39 & 0.00172 & 0 & 0.15802 & 0.49195 & 0 & 0.65170 & 30.91 & 304.06 & 21.000 & V \\
\hline 40 & 0.25306 & $1.3 \mathrm{E}-06$ & 0.17735 & 0.00795 & 0 & 0.43836 & 235.12 & 508.27 & 22.200 & V \\
\hline 41 & 0.25306 & $1.3 \mathrm{E}-06$ & 0.17735 & 0.00795 & 0 & 0.43836 & 130.33 & 403.48 & 21.600 & $\mathrm{~L}+\mathrm{V}$ \\
\hline 42 & 0.25306 & $1.3 \mathrm{E}-06$ & 0.17735 & 0.00795 & 0 & 0.43836 & 48.00 & 321.15 & 21.000 & $\mathrm{~L}+\mathrm{V}$ \\
\hline
\end{tabular}




\begin{tabular}{|c|c|c|c|c|c|c|c|c|c|c|}
\hline 43 & 0.25297 & $1.3 \mathrm{E}-06$ & 0.17252 & 0.00012 & 0 & 0.42562 & 48.00 & 321.15 & 21.000 & $\mathrm{~L}$ \\
\hline 44 & $8.4 \mathrm{E}-05$ & 0 & 0.00483 & 0.00783 & 0 & 0.01274 & 48.00 & 321.15 & 21.000 & V \\
\hline 45 & 17.752 & 5.7650 & 0.85206 & $1.7 E-05$ & 0 & 24.369 & 116.00 & 389.15 & 21.000 & $\mathrm{~L}$ \\
\hline 46 & 21.834 & 5.7659 & 2.0000 & 2E-05 & 0 & 29.600 & 112.57 & 385.72 & 21.000 & $\mathrm{~L}$ \\
\hline 47 & 0.04392 & $3.1 \mathrm{E}-09$ & 0.13931 & 2.9E-06 & 0 & 0.18323 & 105.57 & 378.72 & 1.013 & V \\
\hline 48 & 0.50024 & 8E-07 & 0.04872 & $9.8 \mathrm{E}-05$ & 0 & 0.54905 & 187.36 & 460.51 & 4.000 & V \\
\hline 49 & 0.50024 & $8 \mathrm{E}-07$ & 0.04872 & $9.8 \mathrm{E}-05$ & 0 & 0.54905 & 130.33 & 403.48 & 3.900 & $\mathrm{~L}+\mathrm{V}$ \\
\hline 50 & 0.50024 & $8 \mathrm{E}-07$ & 0.04872 & $9.8 \mathrm{E}-05$ & 0 & 0.54905 & 92.10 & 365.25 & 1.013 & $\mathrm{~L}+\mathrm{V}$ \\
\hline 51 & 0.54416 & $8 \mathrm{E}-07$ & 0.18803 & 0.0001 & 0 & 0.73229 & 48.00 & 321.15 & 0.913 & $\mathrm{~L}+\mathrm{V}$ \\
\hline 52 & 0.02670 & 0 & 0.19038 & 0.0001 & 0 & 0.21718 & 48.00 & 321.15 & 0.913 & V \\
\hline 53 & 0.00495 & 0 & 0.30352 & 0.00623 & 0 & 0.31471 & 48.00 & 321.15 & 21.000 & $\mathrm{~L}+\mathrm{V}$ \\
\hline 54 & 0.00494 & 0 & 0.29896 & $6.4 \mathrm{E}-05$ & 0 & 0.30397 & 48.00 & 321.15 & 21.000 & $\mathrm{~L}$ \\
\hline 55 & 0.01944 & 0 & 0.39780 & $6.4 \mathrm{E}-05$ & 0 & 0.41731 & 47.19 & 320.34 & 21.000 & $\mathrm{~L}$ \\
\hline 56 & 0.03498 & 0 & 0.00099 & 2.4E-08 & 0 & 0.03597 & 48.00 & 321.15 & 2.501 & $\mathrm{~L}$ \\
\hline 57 & 0.03498 & 0 & 0.00099 & $2.4 \mathrm{E}-08$ & 0 & 0.03597 & 49.13 & 322.28 & 21.000 & $\mathrm{~L}$ \\
\hline 58 & 0.0145 & 0 & 0.09884 & $3.9 \mathrm{E}-07$ & 0 & 0.11334 & 48.00 & 321.15 & 7.308 & $\mathrm{~L}$ \\
\hline 59 & 0.0145 & 0 & 0.09884 & $3.9 \mathrm{E}-07$ & 0 & 0.11334 & 49.27 & 322.42 & 21.000 & $\mathrm{~L}$ \\
\hline 60 & $1.1 \mathrm{E}-05$ & 0 & 0.00456 & 0.00616 & 0 & 0.01074 & 48.00 & 321.15 & 21.000 & V \\
\hline 61 & 0.51849 & $8 \mathrm{E}-07$ & 0.005 & 3.9E-09 & 0 & 0.5235 & 48.00 & 321.15 & 0.913 & $\mathrm{~L}$ \\
\hline 62 & 0.51849 & $8 \mathrm{E}-07$ & 0.005 & 3.9E-09 & 0 & 0.5235 & 48.41 & 321.56 & 21.000 & $\mathrm{~L}$ \\
\hline 63 & 0.01473 & $9.6 \mathrm{E}-10$ & 0.00737 & 2.2E-09 & 0 & 0.0221 & 103.47 & 376.62 & 0.330 & V \\
\hline 64 & 0.64799 & $2.5 \mathrm{E}-07$ & 0.00204 & $1.1 \mathrm{E}-07$ & 0 & 0.65004 & 120.33 & 393.48 & 0.330 & V \\
\hline 65 & 0.66272 & $2.5 \mathrm{E}-07$ & 0.00942 & $1.2 \mathrm{E}-07$ & 0 & 0.67214 & 43.00 & 316.15 & 0.230 & $\mathrm{~L}+\mathrm{V}$ \\
\hline 66 & 0.65796 & $2.5 \mathrm{E}-07$ & 0.00151 & 0 & 0 & 0.65947 & 43.00 & 316.15 & 0.230 & $\mathrm{~L}$ \\
\hline 67 & 0.65796 & $2.5 \mathrm{E}-07$ & 0.00151 & 0 & 0 & 0.65947 & 43.38 & 316.53 & 21.000 & $\mathrm{~L}$ \\
\hline 68 & 0.00497 & 0 & 0.00825 & $1.2 \mathrm{E}-07$ & 0 & 0.01323 & 43.00 & 316.15 & 0.230 & V \\
\hline 69 & 0.08905 & 0 & 0 & 0 & 0 & 0.08905 & 169.98 & 443.13 & 7.908 & $\mathrm{~L}+\mathrm{V}$ \\
\hline 70 & 0.09402 & 0 & 0.00825 & $1.2 \mathrm{E}-07$ & 0 & 0.10228 & 137.12 & 410.27 & 1.013 & V \\
\hline 71 & 0.09299 & 0 & 0.0009 & 0 & 0 & 0.09389 & 48.00 & 321.15 & 0.913 & $\mathrm{~L}$ \\
\hline 72 & 0.09299 & 0 & 0.0009 & 0 & 0 & 0.09389 & 48.00 & 321.15 & 1.013 & $\mathrm{~L}$ \\
\hline 73 & 0.00103 & 0 & 0.00736 & $1.2 \mathrm{E}-07$ & 0 & 0.00839 & 48.00 & 321.15 & 0.913 & V \\
\hline 74 & 2.1439 & 0 & 0.0009 & 0 & 0 & 2.1448 & 44.06 & 317.21 & 0.110 & $\mathrm{~L}$ \\
\hline 75 & 2.1439 & 0 & 0.0009 & 0 & 0 & 2.1448 & 44.31 & 317.46 & 21.000 & $\mathrm{~L}$ \\
\hline 76 & 0.00178 & 0 & 0.00036 & 0 & 0 & 0.00215 & 44.06 & 317.21 & 0.110 & V \\
\hline 77 & 0.00404 & 0 & 0 & 0 & 0 & 0.00404 & 169.98 & 443.13 & 7.908 & $\mathrm{~L}+\mathrm{V}$ \\
\hline 78 & 0.00583 & 0 & 0.00036 & 0 & 0 & 0.00619 & 113.41 & 386.56 & 0.330 & V \\
\hline 79 & 0.00562 & 0 & $1.3 \mathrm{E}-05$ & 0 & 0 & 0.00563 & 43.00 & 316.15 & 0.230 & $\mathrm{~L}$ \\
\hline 80 & 0.00562 & 0 & $1.3 \mathrm{E}-05$ & 0 & 0 & 0.00563 & 43.05 & 316.20 & 1.013 & $\mathrm{~L}$ \\
\hline 81 & 0.09861 & 0 & 0.00091 & 0 & 0 & 0.09952 & 47.73 & 320.88 & 1.013 & $\mathrm{~L}$ \\
\hline 82 & 0.00021 & 0 & 0.00035 & 0 & 0 & 0.00056 & 43.00 & 316.15 & 0.230 & V \\
\hline 83 & 2.1162 & 0 & 0.00089 & 0 & 0 & 2.1170 & 44.31 & 317.46 & 21.000 & $\mathrm{~L}$ \\
\hline 84 & 3.3445 & $1.1 \mathrm{E}-06$ & 0.62765 & $8 \mathrm{E}-06$ & 0 & 3.9722 & 86.32 & 359.47 & 21.000 & $\mathrm{~L}$ \\
\hline 85 & 0.01835 & $6.5 \mathrm{E}-10$ & 0.66481 & 0.00065 & 0 & 0.68381 & 112.57 & 385.72 & 21.000 & V \\
\hline 86 & 0.00836 & 0 & 0.21303 & 0.50659 & 0 & 0.72798 & 59.80 & 332.95 & 20.900 & V \\
\hline 87 & 0.02773 & 0 & $1.2 \mathrm{E}-05$ & 0 & 0 & 0.02775 & 44.31 & 317.46 & 21.000 & $\mathrm{~L}$ \\
\hline 88 & 19 & 0 & 0.00011 & 0 & 0 & 19.000 & 48.00 & 321.15 & 21.000 & $\mathrm{~L}$ \\
\hline
\end{tabular}




\begin{tabular}{ccccccccccc}
89 & 19.005 & 0 & 0.21313 & 0.00613 & 0 & 19.224 & 51.93 & 325.08 & 20.900 & $\mathrm{~L}$ \\
90 & 0.00514 & 0 & $5.8 \mathrm{E}-05$ & $1.7 \mathrm{E}-06$ & 0 & 0.0052 & 51.93 & 325.08 & 20.900 & $\mathrm{~L}$ \\
91 & 19 & 0 & 0.21307 & 0.00613 & 0 & 19.219 & 51.93 & 325.08 & 20.900 & $\mathrm{~L}$ \\
92 & 19 & 0 & 0.21307 & 0.00613 & 0 & 19.219 & 52.11 & 325.26 & 1.800 & $\mathrm{~L}+\mathrm{V}$ \\
93 & 19 & 0 & 0.21307 & 0.00613 & 0 & 19.219 & 82.29 & 355.44 & 1.050 & $\mathrm{~L}+\mathrm{V}$ \\
94 & 18.972 & 0 & $9.4 \mathrm{E}-05$ & 0 & 0 & 18.972 & 99.63 & 372.78 & 1.100 & $\mathrm{~L}$ \\
95 & 18.972 & 0 & $9.4 \mathrm{E}-05$ & 0 & 0 & 18.972 & 99.86 & 373.01 & 22.500 & $\mathrm{~L}$ \\
96 & 18.972 & 0 & $9.4 \mathrm{E}-05$ & 0 & 0 & 18.972 & 62.11 & 335.26 & 21.750 & $\mathrm{~L}$ \\
97 & 18.972 & 0 & $9.4 \mathrm{E}-05$ & 0 & 0 & 18.972 & 48.00 & 321.15 & 21.000 & $\mathrm{~L}$ \\
98 & 0.02773 & 0 & 0.21297 & 0.00613 & 0 & 0.24683 & 48.00 & 321.15 & 1.000 & $\mathrm{~V}$ \\
99 & 0.00323 & 0 & $5 \mathrm{E}-07$ & 0.50046 & 0 & 0.50368 & 48.04 & 321.19 & 20.800 & $\mathrm{~V}$ \\
100 & 0 & 0 & 0 & 0.50046 & 0 & 0.50046 & 48.00 & 321.15 & 19.800 & $\mathrm{~V}$ \\
101 & 0.00323 & 0 & $5 \mathrm{E}-07$ & 0 & 0 & 0.00323 & 48.00 & 321.15 & 19.800 & $\mathrm{~L}$ \\
102 & 0.00323 & 0 & $5 \mathrm{E}-07$ & 0 & 0 & 0.00323 & 48.07 & 321.22 & 21.000 & $\mathrm{~L}$ \\
BFW & 0.09309 & 0 & 0 & 0 & 0 & 0.09309 & 38.00 & 311.15 & 1.000 & $\mathrm{~L}$ \\
MAKEUP & 0.0046 & 0.00091 & 0 & 0 & 0 & 0.00552 & 38.00 & 311.15 & 21.000 & $\mathrm{~L}$ \\
STEAM & 0.09309 & 0 & 0 & 0 & 0 & 0.09309 & 170.07 & 443.22 & 7.908 & $\mathrm{~V}$ \\
\hline
\end{tabular}

* Individual component molar flow rates $<1 \times 10^{-9} \mathrm{kmol} / \mathrm{sec}$ are shown as zero. 
Table $3950^{\circ} \mathrm{C}$ ROT HyS process flowsheet energy utilization summary.

Electric power requirements:

EL-01, Electrolyzer

CO-01, $\mathrm{SO}_{2}$ Recycle Compressor

Stage 1

Stage 2

Stage 3

PP-01, Catholyte Feed Pump

PP-02, Vacuum Column Feed Pump

PP-03, Bayonet Reactor Feed Pump

PP-04, Vacuum Column Recycle Pump

PP-05, Anolyte Feed Pump

PP-06, First Stage Intercooler Condensate Pump

PP-07, Second Stage Intercooler Condensate Pump

PP-08, First Flash Stage Vapor Condensate Pump

PP-09, Second Flash Stage Vapor Condensate Pump

PP-10, First Stage Ejector Condensate Pump

PP-11, Vacuum Column Distillate Pump

PP-12, Second Stage Ejector Condensate Pump

$\mathrm{PP}-13, \mathrm{SO}_{2}$ Stripper Bottoms Pump

$\mathrm{PP}-14, \mathrm{O}_{2}$ Dryer Liquids Pump

Total electric power requirement:

Heat recuperation summary:

EX-01, Catholyte Interchanger (EX-01-HS/EX-CS-01, Q1)

EX-02, Anolyte Interchanger (EX-02-HS/EX-CS-01, Q2)

Bayonet Vapor Product Interchangers

Stage 1, EX-03 (EX-03-HS/EX-CS-02, Q3)

Stage 2, EX-04 (EX-04-HS/EX-CS-02, Q4)

Stage 3, EX-05 (EX-05-HS/EX-CS-02, Q5)

EX-06, $\mathrm{SO}_{2}$ Stripper Feed Interchanger

$42.019 \mathrm{MW}_{\text {th }}$

$115.782 \mathrm{MW}_{\mathrm{e}}$

$1.986 \mathrm{MW}_{\mathrm{e}}$

$1.869 \mathrm{MW}_{\mathrm{e}}$

$1.254 \mathrm{MW}_{\mathrm{e}}$

$0.842 \mathrm{MW}_{\mathrm{e}}$

$0.001 \mathrm{MW}_{\mathrm{e}}$

$1.830 \mathrm{MW}_{\mathrm{e}}$

$0.001 \mathrm{MW}_{\mathrm{e}}$

$0.155 \mathrm{MW}_{\mathrm{e}}$

$0.004 \mathrm{MW}_{\mathrm{e}}$

$0.012 \quad \mathrm{MW}_{\mathrm{e}}$

$0.033 \mathrm{MW}_{\mathrm{e}}$

$0.041 \mathrm{MW}_{\mathrm{e}}$

$0.000 \mathrm{MW}_{\mathrm{e}}$

$0.111 \mathrm{MW}_{\mathrm{e}}$

$0.000 \mathrm{MW}_{\mathrm{e}}$

$0.888 \mathrm{MW}_{\mathrm{e}}$

$0.000 \mathrm{MW}_{\mathrm{e}}$

$\underline{124.811} \underline{\mathrm{MW}}_{\mathrm{e}}$

$11.583 \mathrm{MW}_{\text {th }}$

$24.766 \mathrm{MW}_{\text {th }}$

$10.586 \mathrm{MW}_{\text {th }}$

$16.340 \mathrm{MW}_{\text {th }}$

$54.136 \mathrm{MW}_{\text {th }}$

Cooling water requirements:

CO-01 -- $\mathrm{SO}_{2}$ Recycle Compressor Intercoolers

Stage 1

Stage 2

Stage 3

DR-01, Hydrogen Dryer

DR-02, Oxygen Dryer

HX-01, Bayonet Product First Stage Flash Condenser

HX-02, Bayonet Product Second Stage Flash Condenser

HX-03, First Acid Flash Stage Condenser

HX-04, Second Acid Flash Stage Condenser

HX-05, First Stage Ejector Condenser

$3.570 \mathrm{MW}_{\text {th }}$

$4.704 \mathrm{MW}_{\text {th }}$

$7.991 \mathrm{MW}_{\text {th }}$

$6.774 \mathrm{MW}_{\text {th }}$

$0.131 \mathrm{MW}_{\text {th }}$

$20.141 \mathrm{MW}_{\text {th }}$

$6.598 \mathrm{MW}_{\text {th }}$

$9.066 \mathrm{MW}_{\text {th }}$

$30.256 \mathrm{MW}_{\text {th }}$

$4.187 \mathrm{MW}_{\text {th }}$

HX-06, Second Stage Ejector Condenser

$0.258 \mathrm{MW}_{\text {th }}$ 
HX-07, Second Stage $\mathrm{SO}_{2}$ Absorber Feed Cooler

$20.184 \mathrm{MW}_{\text {th }}$

TO-01 Vacuum Column Condenser

$96.383 \mathrm{MW}_{\text {th }}$

TO-04 $\mathrm{SO}_{2}$ Stripper Condenser

$15.891 \mathrm{MW}_{\text {th }}$

Total cooling water requirement:

$\underline{226.133} \mathrm{MW}_{\text {th }}$

High-temperature heat requirements:

Secondary helium supply temperature

$900.0{ }^{\circ} \mathrm{C}$

Minimum helium return temperature (utility pinch)

$514.4{ }^{\circ} \mathrm{C}$

Bayonet Reactor high-temperature heat duty:

$\underline{340.245}{\underline{\mathrm{MW}_{\text {th }}}}$

Low-temperature steam heat requirements:

Vacuum Ejector Steam Feed (100-psig)

TO-01 Vacuum Column Reboiler (30-psig)

TO-04 SO2 Stripper Reboiler (10-psig)

Total low-pressure steam requirement:

Power conversion efficiency $\left(\mathrm{kJ}_{\mathrm{e}} / \mathrm{kJ}_{\mathrm{th}}\right)$

$4.376 \mathrm{MW}_{\text {th }}$

$5.967 \mathrm{MW}_{\text {th }}$

$39.981 \mathrm{MW}_{\text {th }}$

$\underline{50.324} \underline{\mathrm{MW}}_{\text {th }}$

Thermal equivalent of total electric power requirement

$48 \%$

$260.023 \mathrm{MW}_{\text {th }}$

High-temperature (HTGR) heat requirement

$340.245 \mathrm{MW}_{\text {th }}$

$50.324 \mathrm{MW}_{\text {th }}$

$\underline{650.592} \underline{\mathrm{MW}}_{\underline{\underline{h}}}$

Total heat requirement:

$\underline{600.268}{\underline{\mathrm{MW}_{\text {th }}}}$

Total heat requirement (excluding low-pressure steam)*:

$286 \mathrm{MJ} / \mathrm{kmol} \mathrm{H}$

Higher heating value of Hydrogen

$1 \mathrm{kmol} / \mathrm{sec}$

Hydrogen production rate

Equivalent energy content of Hydrogen product

$286 \mathrm{MW}_{\text {th }}$

HHV efficiency upper limit, free steam*

$47.6 \%$

HHV efficiency upper limit

$44.0 \%$

* Assumes that excess 10 - to 100 -psig steam is available on-site at no penalty 
Table $4750^{\circ} \mathrm{C}$ ROT HyS process flowsheet stream table.

\begin{tabular}{|c|c|c|c|c|c|c|c|c|c|c|}
\hline \multirow{2}{*}{$\begin{array}{c}\text { Stream } \\
\text { ID }\end{array}$} & \multicolumn{6}{|c|}{ Molar flow rates, $\mathrm{kmol} / \mathrm{sec}^{*}$} & \multicolumn{2}{|c|}{ Temperature, } & \multirow{2}{*}{$\begin{array}{c}\text { Pressure, } \\
\text { bar }\end{array}$} & \multirow[t]{2}{*}{ Phase } \\
\hline & $\mathrm{H}_{2} \mathrm{O}$ & $\mathrm{H}_{2} \mathrm{SO}_{4}$ & $\mathrm{SO}_{2}$ & $\mathrm{O}_{2}$ & $\mathrm{H}_{2}$ & Total & ${ }^{\circ} \mathrm{C}$ & $\mathrm{K}$ & & \\
\hline 1 & 137.20 & 0 & 0 & 0 & 0.04195 & 137.24 & 115.45 & 388.60 & 22.750 & $\mathrm{~L}$ \\
\hline 2 & 21.834 & 5.7659 & 2 & 4.9E-05 & 0 & 29.600 & 112.50 & 385.65 & 22.750 & $\mathrm{~L}$ \\
\hline 3 & 136.20 & 0 & 0 & 0 & 1.0420 & 137.24 & 120.00 & 393.15 & 21.750 & $\mathrm{~L}+\mathrm{V}$ \\
\hline 4 & 0.10347 & 0 & 0 & 0 & 1 & 1.1035 & 120.00 & 393.15 & 21.750 & V \\
\hline 5 & 0 & 0 & 0 & 0 & 1 & 1 & 48.00 & 321.15 & 20.000 & V \\
\hline 6 & 136.09 & 0 & 0 & 0 & 0.04195 & 136.13 & 120.00 & 393.15 & 21.750 & $\mathrm{~L}$ \\
\hline 7 & 136.09 & 0 & 0 & 0 & 0.04195 & 136.13 & 116.00 & 389.15 & 21.000 & $\mathrm{~L}+\mathrm{V}$ \\
\hline 8 & 0.10347 & 0 & 0 & 0 & 0 & 0.10347 & 48.00 & 321.15 & 20.000 & $\mathrm{~L}$ \\
\hline 9 & 1 & 0 & 0 & 0 & 0 & 1 & 40.00 & 313.15 & 20.000 & $\mathrm{~L}$ \\
\hline 10 & 137.20 & 0 & 0 & 0 & 0.04195 & 137.24 & 115.42 & 388.57 & 20.000 & $\mathrm{~L}+\mathrm{V}$ \\
\hline 11 & 20.834 & 6.7659 & 1 & 4.9E-05 & 0 & 28.600 & 120.00 & 393.15 & 21.750 & $\mathrm{~L}$ \\
\hline 12 & 20.834 & 6.7659 & 1 & $4.9 \mathrm{E}-05$ & 0 & 28.600 & 116.00 & 389.15 & 21.000 & $\mathrm{~L}$ \\
\hline 13 & 3.0796 & 1.0001 & 0.14782 & 7.2E-06 & 0 & 4.2276 & 116.00 & 389.15 & 21.000 & $\mathrm{~L}$ \\
\hline 14 & 3.0796 & 1.0001 & 0.14782 & 7.2E-06 & 0 & 4.2276 & 105.57 & 378.72 & 1.013 & $\mathrm{~L}+\mathrm{V}$ \\
\hline 15 & 3.0357 & 1.0001 & 0.00862 & $5.5 \mathrm{E}-09$ & 0 & 4.0445 & 105.57 & 378.72 & 1.013 & $\mathrm{~L}$ \\
\hline 16 & 3.0357 & 1.0001 & 0.00862 & 5.5E-09 & 0 & 4.0445 & 103.47 & 376.62 & 0.330 & $\mathrm{~L}+\mathrm{V}$ \\
\hline 17 & 3.0210 & 1.0001 & 0.00125 & 0 & 0 & 4.0224 & 103.47 & 376.62 & 0.330 & $\mathrm{~L}$ \\
\hline 18 & 3.0210 & 1.0001 & 0.00125 & 0 & 0 & 4.0224 & 103.47 & 376.62 & 0.430 & $\mathrm{~L}$ \\
\hline 19 & 3.0210 & 1.0001 & 0.00125 & 0 & 0 & 4.0224 & 103.47 & 376.62 & 0.330 & $\mathrm{~L}+\mathrm{V}$ \\
\hline 20 & 3.0210 & 1.0001 & 0.00125 & 0 & 0 & 4.0224 & 115.29 & 388.44 & 0.130 & $\mathrm{~L}+\mathrm{V}$ \\
\hline 21 & 0.6050 & 1.0001 & 0 & 0 & 0 & 1.6051 & 188.36 & 461.51 & 0.130 & $\mathrm{~L}$ \\
\hline 22 & 0.6050 & 1.0001 & 0 & 0 & 0 & 1.6051 & 188.71 & 461.86 & 11.100 & $\mathrm{~L}$ \\
\hline 23 & 5.8682 & 3.4292 & 0.02148 & 0.00113 & 0 & 9.3200 & 256.78 & 529.93 & 11.100 & $\mathrm{~L}$ \\
\hline 24 & 5.8682 & 3.4292 & 0.02148 & 0.00113 & 0 & 9.3200 & 256.88 & 530.03 & 12.700 & $\mathrm{~L}$ \\
\hline 25 & 6.8682 & 2.4292 & 1.02147 & 0.50113 & 0 & 10.820 & 287.73 & 560.88 & 11.700 & $\mathrm{~L}+\mathrm{V}$ \\
\hline 26 & 6.8682 & 2.4292 & 1.0215 & 0.50113 & 0 & 10.820 & 245.69 & 518.84 & 11.100 & $\mathrm{~L}+\mathrm{V}$ \\
\hline 27 & 1.6050 & 0.00013 & 1 & 0.5 & 0 & 3.1051 & 235.00 & 508.15 & 11.100 & V \\
\hline 28 & 1.6050 & 0.00013 & 1 & 0.5 & 0 & 3.1051 & 142.37 & 415.52 & 10.500 & $\mathrm{~L}+\mathrm{V}$ \\
\hline 29 & 1.6050 & 0.00013 & 1 & 0.5 & 0 & 3.1051 & 48.00 & 321.15 & 9.900 & $\mathrm{~L}+\mathrm{V}$ \\
\hline 30 & 0.01718 & 0.00000 & 0.86680 & 0.49987 & 0 & 1.3838 & 48.00 & 321.15 & 9.900 & V \\
\hline 31 & 0.01718 & 0.00000 & 0.86680 & 0.49987 & 0 & 1.3838 & 130.20 & 403.35 & 21.100 & V \\
\hline 32 & 0.01718 & 0.00000 & 0.86680 & 0.49987 & 0 & 1.3838 & 48.00 & 321.15 & 21.000 & $\mathrm{~L}+\mathrm{V}$ \\
\hline 33 & 0.00157 & 0.00000 & 0.36103 & 0.49975 & 0 & 0.86235 & 48.00 & 321.15 & 21.000 & V \\
\hline 34 & 0.01561 & 0.00000 & 0.50577 & 0.00011 & 0 & 0.52149 & 48.00 & 321.15 & 21.000 & $\mathrm{~L}$ \\
\hline 35 & 1.5878 & 0.00013 & 0.13320 & 0.00013 & 0 & 1.7213 & 48.00 & 321.15 & 9.900 & $\mathrm{~L}$ \\
\hline 36 & 1.5878 & 0.00013 & 0.13320 & 0.00013 & 0 & 1.7213 & 48.16 & 321.31 & 21.000 & $\mathrm{~L}$ \\
\hline 37 & 17.754 & 5.7658 & 0.85218 & 4.1E-05 & 0 & 24.372 & 116.00 & 389.15 & 21.000 & $\mathrm{~L}$ \\
\hline 38 & 21.833 & 5.7668 & 1.9991 & 4.9E-05 & 0 & 29.599 & 112.49 & 385.64 & 21.000 & $\mathrm{~L}$ \\
\hline 39 & 0.04389 & $3.1 \mathrm{E}-09$ & 0.13920 & 7.2E-06 & 0 & 0.18309 & 105.57 & 378.72 & 1.013 & V \\
\hline 40 & 0.04389 & $3.1 \mathrm{E}-09$ & 0.13920 & 7.2E-06 & 0 & 0.18309 & 48.00 & 321.15 & 0.913 & $\mathrm{~L}+\mathrm{V}$ \\
\hline 41 & 0.02044 & 0 & 0.14581 & 7.2E-06 & 0 & 0.16625 & 48.00 & 321.15 & 0.913 & V \\
\hline 42 & 0.00664 & 0 & 0.43063 & 0.00610 & 0 & 0.44337 & 48.00 & 321.15 & 21.000 & $\mathrm{~L}+\mathrm{V}$ \\
\hline
\end{tabular}




\begin{tabular}{|c|c|c|c|c|c|c|c|c|c|c|}
\hline 43 & 0.00663 & 0 & 0.42617 & $9.1 \mathrm{E}-05$ & 0 & 0.43290 & 48.00 & 321.15 & 21.000 & $\mathrm{~L}$ \\
\hline 44 & 0.02847 & 0 & 0.58781 & $9.1 \mathrm{E}-05$ & 0 & 0.61638 & 47.24 & 320.39 & 21.000 & $\mathrm{~L}$ \\
\hline 45 & 0.04941 & 0 & 0.00141 & 2.3E-08 & 0 & 0.05082 & 48.00 & 321.15 & 2.501 & $\mathrm{~L}$ \\
\hline 46 & 0.04941 & 0 & 0.00141 & 2.3E-08 & 0 & 0.05082 & 49.13 & 322.28 & 21.000 & $\mathrm{~L}$ \\
\hline 47 & 0.02184 & 0.0000 & 0.16164 & 4.3E-07 & 0 & 0.18348 & 48.00 & 321.15 & 7.308 & $\mathrm{~L}$ \\
\hline 48 & 0.02184 & 0.0000 & 0.16164 & 4.3E-07 & 0 & 0.18348 & 49.08 & 322.23 & 21.000 & $\mathrm{~L}$ \\
\hline 49 & 9.9E-06 & 0 & 0.00445 & 0.00601 & 0 & 0.01047 & 48.00 & 321.15 & 21.000 & V \\
\hline 50 & 0.02441 & 3.1E-09 & 0.00024 & 0 & 0 & 0.02465 & 48.00 & 321.15 & 0.913 & $\mathrm{~L}$ \\
\hline 51 & 0.02441 & 3.1E-09 & 0.00024 & 0 & 0 & 0.02465 & 49.22 & 322.37 & 21.000 & $\mathrm{~L}$ \\
\hline 52 & 0.01472 & $9.6 \mathrm{E}-10$ & 0.00737 & $5.5 \mathrm{E}-09$ & 0 & 0.02208 & 103.47 & 376.62 & 0.330 & V \\
\hline 53 & 0.01472 & $9.6 \mathrm{E}-10$ & 0.00737 & $5.5 \mathrm{E}-09$ & 0 & 0.02208 & 43.00 & 316.15 & 0.230 & $\mathrm{~L}+\mathrm{V}$ \\
\hline 54 & 0.01029 & $9.6 \mathrm{E}-10$ & $2.4 \mathrm{E}-05$ & 0 & 0 & 0.01031 & 43.00 & 316.15 & 0.230 & $\mathrm{~L}$ \\
\hline 55 & 0.01029 & $9.6 \mathrm{E}-10$ & $2.4 \mathrm{E}-05$ & 0 & 0 & 0.01031 & 44.25 & 317.40 & 21.000 & $\mathrm{~L}$ \\
\hline 56 & 0.00463 & 0 & 0.00768 & 5.5E-09 & 0 & 0.01231 & 43.00 & 316.15 & 0.230 & V \\
\hline 57 & 0.08289 & 0 & 0.00000 & 0 & 0 & 0.08289 & 169.98 & 443.13 & 7.908 & $\mathrm{~L}+\mathrm{V}$ \\
\hline 58 & 0.08752 & 0 & 0.00768 & $5.5 \mathrm{E}-09$ & 0 & 0.09520 & 137.12 & 410.27 & 1.013 & $\mathrm{~V}$ \\
\hline 59 & 0.08656 & 0 & 0.00084 & 0 & 0 & 0.08740 & 48.00 & 321.15 & 0.913 & $\mathrm{~L}$ \\
\hline 60 & 0.08656 & 0 & 0.00084 & 0 & 0 & 0.08740 & 48.01 & 321.16 & 1.013 & $\mathrm{~L}$ \\
\hline 61 & 0.00096 & 0 & 0.00685 & $5.5 \mathrm{E}-09$ & 0 & 0.00781 & 48.00 & 321.15 & 0.913 & $\mathrm{~V}$ \\
\hline 62 & 2.4140 & 0 & 0.00090 & 0 & 0 & 2.4149 & 44.57 & 317.72 & 0.110 & $\mathrm{~L}$ \\
\hline 63 & 2.4140 & 0 & 0.00090 & 0 & 0 & 2.4149 & 44.81 & 317.96 & 21.000 & $\mathrm{~L}$ \\
\hline 64 & 0.00206 & 0 & 0.00036 & 0 & 0 & 0.00242 & 44.57 & 317.72 & 0.110 & V \\
\hline 65 & 0.00446 & 0 & 0 & 0 & 0 & 0.00446 & 169.98 & 443.13 & 7.908 & $\mathrm{~L}+\mathrm{V}$ \\
\hline 66 & 0.00652 & 0 & 0.00036 & 0 & 0 & 0.00688 & 113.21 & 386.36 & 0.330 & $\mathrm{~V}$ \\
\hline 67 & 0.00631 & 0 & $1.5 \mathrm{E}-05$ & 0 & 0 & 0.00633 & 43.00 & 316.15 & 0.230 & $\mathrm{~L}$ \\
\hline 68 & 0.00631 & 0 & $1.5 \mathrm{E}-05$ & 0 & 0 & 0.00633 & 43.05 & 316.20 & 1.013 & $\mathrm{~L}$ \\
\hline 69 & 0.09288 & 0 & 0.00085 & 0 & 0 & 0.09373 & 47.68 & 320.83 & 1.013 & $\mathrm{~L}$ \\
\hline 70 & 0.00021 & 0 & 0.00034 & 0 & 0 & 0.00055 & 43.00 & 316.15 & 0.230 & V \\
\hline 71 & 2.3565 & 0 & 0.00088 & 0 & 0 & 2.3574 & 44.81 & 317.96 & 21.000 & $\mathrm{~L}$ \\
\hline 72 & 2.4481 & 4.4E-09 & 0.24974 & 0.00046 & 0 & 2.6983 & 68.67 & 341.82 & 21.000 & $\mathrm{~L}$ \\
\hline 73 & 0.00908 & $3.2 \mathrm{E}-10$ & 0.32955 & 0.00079 & 0 & 0.33942 & 112.49 & 385.64 & 21.000 & $\mathrm{~V}$ \\
\hline 74 & 0.01532 & 0 & 0.44811 & 0.50610 & 0 & 0.96953 & 66.64 & 339.79 & 20.900 & V \\
\hline 75 & 0.05746 & 0 & $2.1 \mathrm{E}-05$ & 0 & 0 & 0.05748 & 44.81 & 317.96 & 21.000 & $\mathrm{~L}$ \\
\hline 76 & 20.000 & 0 & 0.00010 & 0 & 0 & 20.000 & 48.00 & 321.15 & 21.000 & $\mathrm{~L}$ \\
\hline 77 & 20.012 & 0 & 0.44821 & 0.00610 & 0 & 20.466 & 55.37 & 328.52 & 20.900 & $\mathrm{~L}$ \\
\hline 78 & 0.0121 & 0 & 0.00027 & $3.7 \mathrm{E}-06$ & 0 & 0.01237 & 55.37 & 328.52 & 20.900 & $\mathrm{~L}$ \\
\hline 79 & 20 & 0 & 0.44794 & 0.00609 & 0 & 20.454 & 55.37 & 328.52 & 20.900 & $\mathrm{~L}$ \\
\hline 80 & 20 & 0 & 0.44794 & 0.00609 & 0 & 20.454 & 53.60 & 326.75 & 1.800 & $\mathrm{~L}+\mathrm{V}$ \\
\hline 81 & 20 & 0 & 0.44794 & 0.00609 & 0 & 20.454 & 79.69 & 352.84 & 1.050 & $\mathrm{~L}+\mathrm{V}$ \\
\hline 82 & 19.943 & 0 & 7.9E-05 & 0 & 0 & 19.943 & 102.31 & 375.46 & 1.100 & $\mathrm{~L}$ \\
\hline 83 & 19.943 & 0 & 7.9E-05 & 0 & 0 & 19.943 & 102.55 & 375.70 & 22.500 & $\mathrm{~L}$ \\
\hline 84 & 19.943 & 0 & 7.9E-05 & 0 & 0 & 19.943 & 63.60 & 336.75 & 21.750 & $\mathrm{~L}$ \\
\hline 85 & 19.943 & 0 & 7.9E-05 & 0 & 0 & 19.943 & 48.00 & 321.15 & 21.000 & $\mathrm{~L}$ \\
\hline 86 & 0.05746 & 0 & 0.44786 & 0.00609 & 0 & 0.51141 & 48.00 & 321.15 & 1.000 & $\mathrm{~L}+\mathrm{V}$ \\
\hline 87 & 0.00322 & 0 & $5 \mathrm{E}-07$ & 0.5 & 0 & 0.50322 & 48.04 & 321.19 & 20.800 & $\mathrm{~V}$ \\
\hline 88 & 0 & 0 & 0 & 0.5 & 0 & 0.5 & 48.04 & 321.19 & 19.800 & V \\
\hline
\end{tabular}




\begin{tabular}{ccccccccccc}
89 & 0.00322 & 0 & $5 E-07$ & 0 & 0 & 0.00322 & 48.04 & 321.19 & 19.800 & $\mathrm{~L}$ \\
90 & 0.00322 & 0 & $5 \mathrm{E}-07$ & 0 & 0 & 0.00322 & 48.11 & 321.26 & 21.000 & $\mathrm{~L}$ \\
BFW & 0.08735 & 0 & 0 & 0 & 0 & 0.08735 & 38.00 & 311.15 & 1.000 & $\mathrm{~L}$ \\
MAKEUP & 0.00468 & 0.00085 & 0 & 0 & 0 & 0.00553 & 38.00 & 311.15 & 21.000 & $\mathrm{~L}$ \\
STEAM & 0.08735 & 0 & 0 & 0 & 0 & 0.08735 & 170.08 & 443.23 & 7.910 & $\mathrm{~V}$ \\
DT1 & & & & & & $2.9636 \dagger$ & 120.00 & 393.15 & 2.000 & $\mathrm{~L}$ \\
DT2 & & & & & & $2.9636 \dagger$ & 120.13 & 393.28 & 6.500 & $\mathrm{~L}$ \\
DT3 & & & & & $2.9636 \dagger$ & 153.84 & 426.99 & 5.750 & $\mathrm{~L}$ \\
DT4 & & & & & $2.9636 \dagger$ & 156.38 & 429.53 & 5.000 & $\mathrm{~L}$ \\
DT5 & & & & & $2.9636 \dagger$ & 250.00 & 523.15 & 4.250 & $\mathrm{~L}$ \\
DT6 & & & & & $2.9636 \dagger$ & 246.91 & 520.06 & 3.500 & $\mathrm{~L}$ \\
DT7 & & & & & $2.9636 \dagger$ & 164.43 & 437.58 & 2.750 & $\mathrm{~L}$ \\
\hline
\end{tabular}

* Individual component molar flow rates $<1 \times 10^{-9} \mathrm{kmol} / \mathrm{sec}$ are shown as zero.

$\dagger$ Molar flow rate of DOWTHERM G, kmol/sec. 
Table $5750^{\circ} \mathrm{C}$ ROT HyS process flowsheet energy utilization summary.

Electric power requirements:

EL-01, Electrolyzer

$\mathrm{CO}-01, \mathrm{SO}_{2}$ Recycle Compressor

Stage 1

Stage 2

Stage 3

CO-02, $\mathrm{SO}_{2} / \mathrm{O}_{2}$ Compressor

PP-01, Catholyte Feed Pump

PP-02, Vacuum Column Feed Pump

PP-03, Quench Column Feed Pump

PP-04, Bayonet Reactor Feed Pump

PP-05, Quench Column Overhead Condensate Pump

PP-06, Anolyte Feed Pump

PP-07, First Stage Intercooler Condensate Pump

PP-08, Second Stage Intercooler Condensate Pump

PP-09, First Flash Stage Vapor Condensate Pump

PP-10, Second Flash Stage Vapor Condensate Pump

PP-11, First Stage Ejector Condensate Pump

PP-12, Vacuum Column Distillate Pump

PP-13, Second Stage Ejector Condensate Pump

PP-14, $\mathrm{SO}_{2}$ Stripper Bottoms Pump

PP-15, $\mathrm{O}_{2}$ Dryer Liquids Pump

PP-16, Dowtherm Pump

Total electric power requirement:

\begin{aligned} & 115.782 $\mathrm{MW}_{\mathrm{e}} \\ & 2.900 \mathrm{MW}_{\mathrm{e}} \\ & 2.736 \mathrm{MW}_{\mathrm{e}} \\ & 1.765 \mathrm{MW}_{\mathrm{e}} \\ & 3.983 \mathrm{MW}_{\mathrm{e}} \\ & 0.837 \mathrm{MW}_{\mathrm{e}} \\ & 0.001 \mathrm{MW}_{\mathrm{e}} \\ & 0.096 \mathrm{MW}_{\mathrm{e}} \\ & 0.067 \mathrm{MW}_{\mathrm{e}} \\ & 0.052 \mathrm{MW}_{\mathrm{e}} \\ & 0.155 \mathrm{MW}_{\mathrm{e}} \\ & 0.006 \mathrm{MW}_{\mathrm{e}} \\ & 0.017 \mathrm{MW}_{\mathrm{e}} \\ & 0.003 \mathrm{MW}_{\mathrm{e}} \\ & 0.001 \mathrm{MW}_{\mathrm{e}} \\ & 0.000 \mathrm{MW}_{\mathrm{e}} \\ & 0.124 \mathrm{MW}_{\mathrm{e}} \\ & 0.000 \mathrm{MW}_{\mathrm{e}} \\ & 0.935 \mathrm{MW}_{\mathrm{e}} \\ & 0.000 \mathrm{MW}_{\mathrm{e}} \\ & 0.332 \mathrm{MW}_{\mathrm{e}} \\ & 129.795 \underline{\mathrm{MW}}_{\mathrm{e}} \\ &$\hline\end{aligned}

Heat recuperation summary:

EX-01, Catholyte Interchanger (EX-01-HS/EX-CS-01, Q1)

$41.772 \mathrm{MW}_{\text {th }}$

EX-02, Anolyte Interchanger (EX-02-HS/EX-CS-01, Q2)

$11.583 \mathrm{MW}_{\text {th }}$

$\mathrm{EX}-03, \mathrm{SO}_{2}$ Stripper Feed Interchanger

$58.748 \mathrm{MW}_{\text {th }}$

Cooling water requirements:

CO-01 -- $\mathrm{SO}_{2}$ Recycle Compressor Intercoolers

Stage 1

Stage 2

Stage 3

DR-01, Hydrogen Dryer

DR-02, Oxygen Dryer

HX-03, Quench Column Overhead Cooler

HX-04, $\mathrm{SO}_{2} / \mathrm{O}_{2}$ Compressor Effluent Cooler

HX-05, First Acid Flash Stage Condenser

HX-06, Second Acid Flash Stage Condenser

HX-07, First Stage Ejector Condenser

HX-08, Second Stage Ejector Condenser

HX-09, Second Stage $\mathrm{SO}_{2}$ Absorber Feed Cooler

$\begin{aligned} 5.139 & \mathrm{MW}_{\text {th }} \\ 7.277 & \mathrm{MW}_{\text {th }} \\ 11.354 & \mathrm{MW}_{\text {th }} \\ 6.774 & \mathrm{MW}_{\text {th }} \\ 0.131 & \mathrm{MW}_{\text {th }} \\ 55.332 & \mathrm{MW}_{\text {th }} \\ 15.818 & \mathrm{MW}_{\text {th }} \\ 1.478 & \mathrm{MW}_{\text {th }} \\ 0.494 & \mathrm{MW}_{\text {th }} \\ 3.902 & \mathrm{MW}_{\text {th }} \\ 0.290 & \mathrm{MW}_{\text {th }} \\ 23.450 & \mathrm{MW}_{\text {th }}\end{aligned}$


TO-01 Vacuum Column Condenser

TO-02 Quench Column Condenser

\begin{aligned} & 115.140 $\mathrm{MW}_{\text {th }} \\ & 2.861 \mathrm{MW}_{\text {th }} \\ & 24.644 \mathrm{MW}_{\text {th }} \\ & 274.084 \mathrm{MW}_{\text {th }} \\ &$\hline\end{aligned}

TO-04 $\mathrm{SO}_{2}$ Stripper Condenser

Total cooling water requirement:

Intermediate temperature heat sources:

HX-01, Bayonet Reactor Effluent Cooler

Inlet Temperature:

Outlet Temperature:

TO-02 Quench Column Condenser

Inlet Temperature:

Outlet Temperature:

HX-02, Quench Column Overhead Cooler

Inlet Temperature:

Outlet Temperature:

Total intermediate temperature heat sources:

$\begin{aligned} 115.571 & \mathrm{MW}_{\text {th }} \\ 287.7 & { }^{\circ} \mathrm{C} \\ 245.7 & { }^{\circ} \mathrm{C} \\ 2.861 & \mathrm{MW}_{\text {th }} \\ 256.8 & { }^{\circ} \mathrm{C} \\ 235.0 & { }^{\circ} \mathrm{C} \\ 37.010 & \mathrm{MW}_{\text {th }} \\ 234.4 & { }^{\circ} \mathrm{C} \\ 142.4 & { }^{\circ} \mathrm{C} \\ 155.443 & \mathrm{MW}_{\text {th }}\end{aligned}$

Intermediate temperature heat sinks:

TO-01 Vacuum Column Reboiler

Inlet Temperature:

Outlet Temperature:

$102.309 \mathrm{MW}_{\text {th }}$

$114.8{ }^{\circ} \mathrm{C}$

$188.4{ }^{\circ} \mathrm{C}$

TO-05 $\mathrm{SO}_{2}$ Stripper Reboiler

Inlet Temperature:

Outlet Temperature:

SG-01, Steam Generator

Inlet Temperature:

Outlet Temperature:

Total intermediate temperature heat sinks:

High-temperature heat requirements:

Secondary helium supply temperature

Minimum helium return temperature (utility pinch)

Bayonet Reactor high-temperature heat duty:

Power conversion efficiency $\left(\mathrm{kJ}_{\mathrm{e}} / \mathrm{kJ}_{\mathrm{th}}\right)$

$49.027 \mathrm{MW}_{\text {th }}$

$101.9{ }^{\circ} \mathrm{C}$

$102.3{ }^{\circ} \mathrm{C}$

$4.106 \mathrm{MW}_{\text {th }}$

$37.9{ }^{\circ} \mathrm{C}$

$170.1{ }^{\circ} \mathrm{C}$

$\underline{155.443} \mathrm{MW}_{\text {th }}$

Thermal equivalent of total electric power requirement

High-temperature (HTGR) heat requirement

Total heat requirement:

$700.0{ }^{\circ} \mathrm{C}$

$425.5{ }^{\circ} \mathrm{C}$

$\underline{428.291} \underline{\mathrm{MW}}_{\underline{t h}}$

$45 \%$

$288.433 \mathrm{MW}_{\text {th }}$

$428.291 \mathrm{MW}_{\text {th }}$

$\underline{716.724} \underline{\text { MW }}_{\text {th }}$

Higher heating value of Hydrogen

$286 \mathrm{MJ} / \mathrm{kmol} \mathrm{H}$

Hydrogen production rate

Equivalent energy content of Hydrogen product

$1 \mathrm{kmol} / \mathrm{sec}$

$286 \mathrm{MW}_{\text {th }}$

HHV efficiency upper limit

$39.9 \%$ 